\title{
Direct or indirect electrification? A review of heat generation and road transport decarbonisation scenarios for Germany 2050
}

\author{
Oliver Ruhnau ${ }^{\mathrm{a}, *}$, Sergej Bannik ${ }^{\mathrm{a}}$, Sydney Otten ${ }^{\mathrm{a}}$, Aaron Praktiknjo ${ }^{\mathrm{a}, \mathrm{b}}$, Martin Robinius ${ }^{\mathrm{c}, \mathrm{d}}$ \\ ${ }^{a}$ Institute for Future Energy Consumer Needs and Behavior (FCN), RWTH Aachen University, Mathieustr. 10, 52075 Aachen, Germany. \\ ${ }^{\mathrm{b}}$ JARA-ENERGY, 52074 Aachen, Germany. \\ ${ }^{\mathrm{c}}$ Institute of Energy and Climate Research: Electrochemical Process Engineering IEK-3, Forschungszentrum Jülich GmbH, 52425 Jülich, Germany. \\ d JARA-ENERGY, 52428 Jülich, Germany. \\ * Corresponding author: oliver.ruhnau@ rwth-aachen.de.
}

\section{HIGHLIGHTS}

- In the scenarios reviewed, GHG emission reduction targets drive electrification.

- If targets are met by $2050,40-100 \%$ of heat and car transport will be electrified.

- The electricity consumption of heat and transport will increase to 400-800 TWh.

- Heat generation, at least in the building sector, favours direct electrification.

- Preferable electrification paths and technologies for road transport are unclear.

\begin{abstract}
Energy scenarios provide guidance to energy policy, not least by presenting decarbonisation pathways for climate change mitigation. We review such scenarios for the example of Germany 2050 with a focus on the decarbonisation of heat generation and road transport. In this context, we characterize the role of renewable electricity and contrast two rivalling narratives: direct electrification, using electric heat pumps, electric heaters, and battery electric vehicles, versus indirect electrification, using gas heat pumps, gas heaters, fuel cell electric vehicles, and internal combustion engine vehicles, in combination with power-to-gas and power-to-liquid processes. To GHG emission reduction targets, our findings imply for energy stakeholders to (1) plan for the significant additional demand for renewable electricity for heat and road transport, (2) pave the way for system-friendly direct heat electrification, (3) be aware of technological uncertainty in the transport sector, (4) clarify the decarbonisation vision, particularly for road transport, and (5) use holistic and more comparable scenario frameworks.
\end{abstract}

\section{KEYWORDS}

Energy transition, energy scenarios, electrification, decarbonisation, energy end-use.

\section{CITATION}

Ruhnau O, Bannik S, Otten S, Praktiknjo A, and Robinius M. Direct or indirect electrification? A review of heat generation and road transport decarbonisation scenarios for Germany 2050. Energy, 2019;166:989-99. https://doi.org/10.1016/j.energy.2018.10.114 


\section{INTRODUCTION}

In line with the Paris Agreement [1], Germany aims to reduce its GHG emissions by 80-95\% [2, 3]. Today, around $85 \%$ of these emissions are energy-related, more precisely related to electricity generation (43\%), heat generation (34\%) and road transport (22\%) [4]. Hence, the decarbonisation of these three energy applications is pivotal to reach the climate policy targets. As the rise of wind and solar energy in the electricity sector gains momentum, the focus of the German energy policy shifts towards their variable electricity output. Not only is renewable electricity considered a major option for the decarbonisation of the electricity sector, but also might it imply challenges for the electricity system balance. Furthermore, it could potentially fuel the decarbonisation of the yet largely non-electric energy end-uses heat generation and road transport.

Further integration of electricity into energy end-use applications can follow different paths, which we refer to as direct and indirect electrification (Figure 1). In the category of direct electrification, we include the devices providing heat and road transport that directly use electricity as an input. For heat generation, this is obviously the case for all kinds of electric heaters but also for electric heat pumps, which additionally exploit ambient or waste heat. For road transport, our definition of direct electrification includes battery electric vehicles, the battery-fuelled mileage of plug-in hybrids, and trolley vehicles, which take electricity from overhead wires. In contrast, our concept of indirect electrification implies that the heating and transport devices indirectly consume electricity in the form of synthetic fuels. Thus, the indirect electrification firstly always comprises a fuel synthesis, e.g. electrolysis for synthetic hydrogen and methanation for synthetic methane, and is therefore usually discussed under the heading of power-to-gas or power-to-liquid (e.g. Götz et al. [5] and Schiebahn et al. [6]). Secondly, the synthetic fuel is converted into heat, using gas heaters, gas heat pumps and cogeneration plants (with simultaneous electricity output), or into traction energy, using fuel cell electric vehicles and internal combustion engines. It is noteworthy that the use of synthetic fuels is not limited to our definition of indirect electrification, which excludes their reconversion to electricity to provide long-term power-to-power storage.

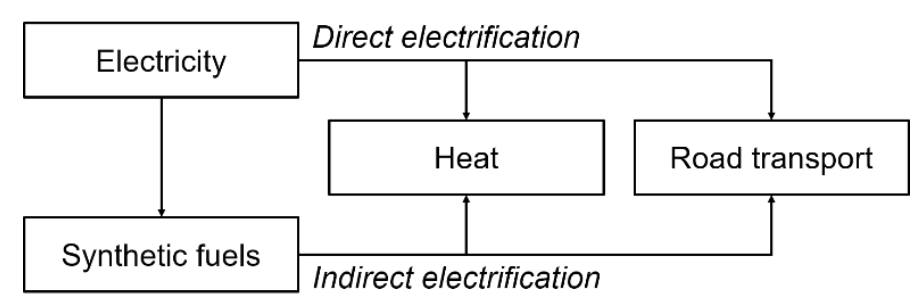

Figure 1: Direct and indirect electrification of heat and road transport. 
Direct and indirect electrification are competitors for the flexible use of renewable electricity as well as for the decarbonisation of heat and road transport. The outcome of this rivalry, the dominance or a combination of direct or indirect paths, is not trivial as both options feature advantages and disadvantages. For example, the direct paths are generally superior in terms of efficiency, while the indirect paths are more suitable for long-term storage [7, 8]. Furthermore, many of the electrification technologies have not reached maturity yet, so that their eventual performance is subject to uncertainty.

Existing energy scenario reviews have ignored this interdependency whilst focusing on electricity only [9], or on either direct electrification [10] or indirect electrification, e.g. on hydrogen futures [11]. Yet, these studies identify climate change and the resulting need for decarbonisation as key drivers for both electrification types.

This study aims to fill this gap with a comparative analysis of various electrification paths in published energy scenarios that answers the following questions. What role will the electrification of heat and road transport play in future energy systems? How much additional renewable electricity will be needed for newly electrified energy end-uses? To what extent do direct and indirect electrification substitute and complement each other?

Our analysis summarizes the results of a variety of 22 energy scenarios for the example of Germany 2050, which are presented in section 2. Despite the regional focus, we think our analysis is representative and informative also for other countries, probably with restriction to temperate climate countries for the analysis of heat generation. To provide some recent examples, direct electrification scenarios are discussed by Quiggin and Buswell [12] for the UK and presented by Jacobson et al. [13] for 139 countries of the world, and indirect electrification is proposed by Scamman and Newborough [14] for France and by Vo et al. [15] for Ireland. To enable an appropriate and concise comparison of direct and indirect electrification in energy scenarios, we present a novel evaluation and visualization framework as described in section 3. Particularly, we focus on the share of direct and indirect electrification in terms of useful energy rather than the share of electricity in final energy as it was used by Edmonds et al. [16] and Sugiyama [10]. The results of our analysis are presented in section 4 from the perspectives of the electricity system, of heat generation, and of road transport, in turn. For a better interpretation of our findings on the scenario results, we complement our evaluation with a review of the underlying technological assumptions. Section 5 concludes with implications for policy makers, scenario builders, and other stakeholders in the field of energy. 


\section{REVIEWED ENERGY SCENARIOS}

As shown by Robinius et al. [17], studies on the future of the German energy system started to consider substantial additional electricity consumption for an increasing energy end-use electrification only recently, since 2014. In our evaluation, we focus on 12 of these studies with a total number of 22 scenarios (Table 1). To allow for a meaningful comparison and interpretation of the results, various studies and scenarios are distinguished by two criteria: the GHG emission reduction that is achieved and the energy end-use applications of which the electrification has been explicitly considered.

Table 1: Studies reviewed in this paper.

\begin{tabular}{|c|c|c|c|c|c|c|c|c|}
\hline \multirow[b]{2}{*}{ No. } & \multirow[b]{2}{*}{ Reference } & \multicolumn{2}{|c|}{ Heat Electrification } & \multicolumn{2}{|c|}{ Transport Electrification } & \multicolumn{3}{|c|}{$\Delta$ GHG } \\
\hline & & Buildings & Industry & Cars & Trucks & Trend & $\geq 80 \%$ & $\geq 85 \%$ \\
\hline 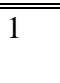 & $\begin{array}{l}\text { DLR et al. [18] } \\
\end{array}$ & & & $\checkmark$ & $\checkmark$ & & $\begin{array}{l}80 \% \\
80 \%\end{array}$ & \\
\hline 2 & Oeko-Institut [19] & & & $\checkmark$ & $\checkmark$ & & $84 \%$ & $90 \%$ \\
\hline 3 & Prognos et al. [20] & $\checkmark$ & $\sqrt{ }$ & $\checkmark$ & $\checkmark$ & $65 \%$ & $80 \%$ & \\
\hline 4 & UBA [21] & $\checkmark$ & implicit & $\checkmark$ & $\checkmark$ & & & $100 \%$ \\
\hline 5 & DLR et al. [22] & & & $\sqrt{ }$ & $\sqrt{ }$ & & $\begin{array}{l}80 \% \\
80 \% \\
80 \%\end{array}$ & \\
\hline 6 & Heilek [23] & $\checkmark$ & & & & & $80 \%$ & \\
\hline 7 & $\begin{array}{l}\text { Oeko-Institut and } \\
\text { Fraunhofer ISI [24] }\end{array}$ & $\checkmark$ & implicit & $\checkmark$ & $\checkmark$ & $54 \%$ & $80 \%$ & $95 \%$ \\
\hline 8 & Robinius [25] & & & $\checkmark$ & & & $80 \%$ & \\
\hline 9 & Nitsch $[26]^{\mathrm{a}}$ & $\checkmark$ & $\checkmark$ & $\checkmark$ & $\checkmark$ & $58 \%$ & & $95 \%$ \\
\hline 10 & Palzer [28] & $\sqrt{ }$ & implicit & $\sqrt{ }$ & $\sqrt{ }$ & & $80 \%$ & $86 \%$ \\
\hline 11 & Quaschning [29] & $\checkmark$ & $\checkmark$ & $\checkmark$ & $\checkmark$ & & & $100 \%$ \\
\hline 12 & $\begin{array}{l}\text { Fraunhofer IWES/IBP } \\
{[30]^{c}}\end{array}$ & $\checkmark$ & $\checkmark$ & $\checkmark$ & $\checkmark$ & & $83 \%$ & $95 \%$ \\
\hline
\end{tabular}

${ }^{a}$ The study presents three scenarios in total, but the two $95 \%$ scenarios are very similar for the year 2050. Thus, we evaluate only one of the 95\% scenarios (KLIMA 2050). Note that this study is an updated version of the well-known study from DLR et al. (2012).

b This study assumes that the German emission target has already to be reached by 2040. Thus, a scenario for the German energy system in 2040 is presented, but it is very comparable to other studies' 2050 scenarios.

${ }^{c}$ Numerical details are retrieved from data appendix. Note that this study is an updated and extended version of the study from Fraunhofer IWES et al. (2015), which provides further transport scenarios at $80 \%$ GHG reduction that we evaluate in subsection 4.3 . 
The $1.5^{\circ} \mathrm{C}$ target and $2{ }^{\circ} \mathrm{C}$ limit of the Paris Agreement translates into an 80-95\% reduction of GHG emissions in the EU, which is also the declared objective of German climate policy [2,3]. Accordingly, we introduce the following clusters, which are applied to the scenarios in Table 1:

1. Trend: This cluster comprises all business-as-usual scenarios that do not meet the emission reduction target. Across all the reviewed studies, there are three scenarios fitting into this cluster, in which emissions are reduced by $54-65 \%$.

2. $\quad$ GGHG $\geq 80 \%$ : This cluster gathers all scenarios in which emissions are reduced sufficiently to reach the lower bound of the climate target (at least by 80\%) but not much further (maximally by $84 \%$ ). Most of the scenarios reviewed (13) belongs to this cluster.

3. $\mathbf{A G H G} \geq \mathbf{8 5 \%}$ : This cluster consists of all scenarios, where the emissions are reduced by $85 \%$ or more. Seven scenarios are associated with this cluster. In two of them, energy-related emissions are even completely mitigated $(\Delta \mathrm{GHG}=100 \%)$.

Regarding the energy end-use applications, we distinguish between heat for buildings and for industrial processes as well as between cars and trucks, which proves useful for our scenario evaluation (cf. section 3). As it can be seen in Table 1, several studies are restricted to heat applications in buildings [23], to road transport [18, 19, 22], or to car transport [25]. Furthermore, Oeko-Institut and Fraunhofer ISI [24], Palzer [28], and UBA [21] provide no explicit information on heat for industrial processes but present only aggregated results for heat and non-heat applications in the industry sector. Likewise, Nitsch [26] and Prognos et al. [20] only allow for drawing conclusions on the aggregated road transport, i.e. cars and trucks cannot be distinguished as necessary for our evaluation. Note that some studies also include non-road transport and some even consider its electrification (e.g. Quaschning [29] and Oeko-Institut and Fraunhofer ISI [24]), but this is beyond the scope of this study.

Some studies present several scenarios for the same end-use applications with the same mitigation target. These scenarios can be distinguished by the ex-ante defined mix of transport decarbonisation technologies. The two mitigation scenarios by DLR et al. [18] contrast a focus on synthetic methane with a mix of synthetic methane, synthetic hydrogen, and battery electric vehicles. Similarly, DLR et al. [22] present one scenario with mainly direct electrification, another with mainly synthetic methane, and a third with mainly synthetic hydrogen. 


\section{REVIEW METHODOLOGY}

We characterize the expected role of direct and indirect electrification of heat and road transport in the German energy system in 2050 from two different perspectives: the electricity system and the energy end-uses.

From the electricity system's point of view, we determine the electricity consumption for heat and road transport, which we distinguish by two dimensions: subject of electrification, i.e. heat generation and road transport, and type of electrification, i.e. direct and indirect. Regarding indirect electrification, we identify the amount of electricity that is converted into synthetic gases and, unless otherwise stated in the studies, we partly assign it to heat generation and road transport according to the share of these enduses in the total gas consumption.

From the energy end-use perspective, we calculate the share of electrification in terms of useful energy:

$$
\text { share of electrification }=\frac{\text { electrified useful energy demand }}{\text { total useful energy demand }}
$$

We think that useful energy enables a more intuitive interpretation as it is directly related to the energy end-use, in contrast to final energy as evaluated by Edmonds et al. [16] and Sugiyama [10], which also depends on the final-to-useful-energy conversion efficiency. For example, if every second car is a battery electric vehicle and every second mile is driven electrically, the electrification share in useful energy will be $50 \%$. In contrast, the electrification share in final energy will be much lower because the conversion efficiency is higher for electric drives than for combustion engines. Similar effects occur when comparing electric heat pumps to conventional boilers.

Consequently, the electrification share in heat generation is quantified in terms of useful heat ${ }^{1}$. Within the heat demand, we distinguish between heat applications in buildings, which include space heating and warm water, and heat for industrial processes to account for the specific characteristics of each of these applications. For example, industrial processes require heat at a much higher temperature level than space heating, which has implications on the applicability of heat pumps for electrification. Note that heat for buildings and for industrial processes cannot be separated consistently for all studies, as some report aggregated results for the industry sector including both processes and buildings (e.g. Nitsch [26]), while others separate industrial processes and buildings (e.g. Fraunhofer IWES/IBP [30]). However, the impacts of this inaccuracy should be limited, as the heat demand for buildings in the

\footnotetext{
${ }^{1}$ For some studies, which report final energy only, we transform the reported values into useful heat. If the relevant conversion efficiencies are not stated in the respective study, we consider the average efficiency of all other studies.
} 
industry sector is small as compared to the heat demand for industrial processes and the heat demand for other buildings (53 TWh as compared to $468 \mathrm{TWh}$ and $726 \mathrm{TWh}$ in 2015 [32]).

For the electrification share in road transport, useful energy can be quantified in terms of traction energy, as used by Palzer [28]. For most of the studies, however, traction energy is not reported, and we consider the mileage as a proxy for the useful energy. We distinguish between cars and trucks as they feature substantially different requirements in terms of weight, range and, eventually, in terms of energy demand. Also, the unit of the mileage differs: vehicle kilometres for the case of cars and ton kilometres for the case of trucks. The exact vehicle categories vary across the studies reviewed, e.g. light-duty vehicles are attributed to cars in some cases (e.g. Fraunhofer IWES/IBP [30]) and aggregated with trucks in others (e.g. Oeko-Institut [19]). Further inaccuracies are due to motorized two-wheelers and busses. However, the implications of these inaccuracies should be limited, as cars and trucks are very dominant in road transport as compared to other vehicle types.

Whereas calculating the direct electrification share is straightforward, the indirect electrification share involves some complexity as synthetic fuels are often not explicitly assigned to heat and transport applications in the scenarios. If so, as for the calculation of electricity consumption, we partly assign synthetic fuels to applications according to the share of these applications in the total fuel consumption.

For the presentation of the results, we use a novel visualization framework inspired by operations research (e.g. Dantzig [33]). We interpret the above-defined electricity consumption for electrification and the electrification shares of heat and road transport as decision variables. In our figures, we display these variables in pairs on the axes of a two-dimensional coordinate system. When only considering the restriction that all variables must be greater than zero, the first quadrant in the coordinate system defines solution space, i.e. all possible combinations of the decision variables. For the case of electrification shares, the solution space is further limited by the total electrification of heat and road transport (100\%). Every scenario is represented as one point in the figures, i.e. one concrete combination of the decision variables out of all possible combinations. Of course, the number of possible combinations is further limited by technical and political restrictions, but these vary across different scenarios and cannot be generalized. However, we will display one of these scenario-specific constraints, which is particularly interesting in the context of decarbonisation: the GHG reduction target is indicated by the colour of the points (the darker the point the more ambitious the mitigation target). In fact, many energy scenarios rely on mathematical models, but the decision variables and constraints are more numerous. By focusing on direct and indirect electrification of heat and road transport, we reduce this complexity and enable an informative comparison of various scenarios. Furthermore, conclusions can be drawn on how these are related to decarbonisation targets. 


\section{RESULTS}

This section presents the results of the scenario review focusing on the electricity consumption for heat and road transport (subsection 4.1) and on the electrification shares of heat (subsection 4.2) and road transport (subsection 4.3), in turn. Finally, the underlying technology assumptions are reviewed and linked to the preceding findings (subsection 4.4).

\subsection{Electricity consumption for heat and road transport}

Few scenarios cover the whole spectrum of heat and road transport such that there is a trade-off between presenting as complete information as possible and including as many studies as possible. Therefore, we evaluate the electricity consumption for electrification twice: once considering all heat and road transport applications with only few scenarios (6) and once more considering heat only for buildings, i.e. heat for industrial processes is excluded, with a more significant number of scenarios (12).
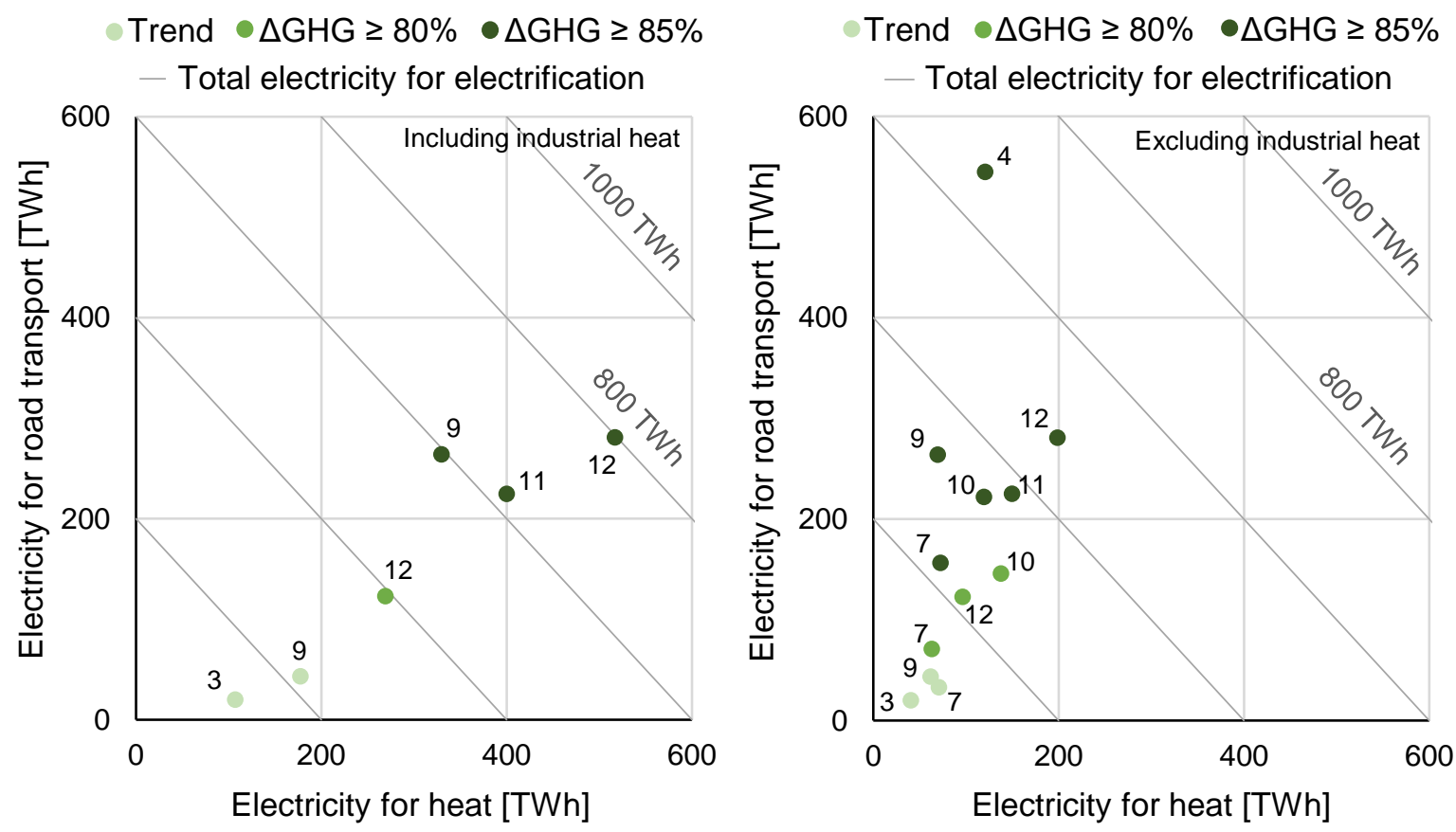

Figure 2 presents a break-down of the electricity consumption by the first dimension of our analysis: subject of electrification. Thus, in the context of our visualization framework, the electricity consumption for road transport and the electricity consumption for heat are the two "decision variables" on the axes that define the position of the scenario points. The diagonal contour lines indicate the total electricity consumption for both heat generation and road transport. 

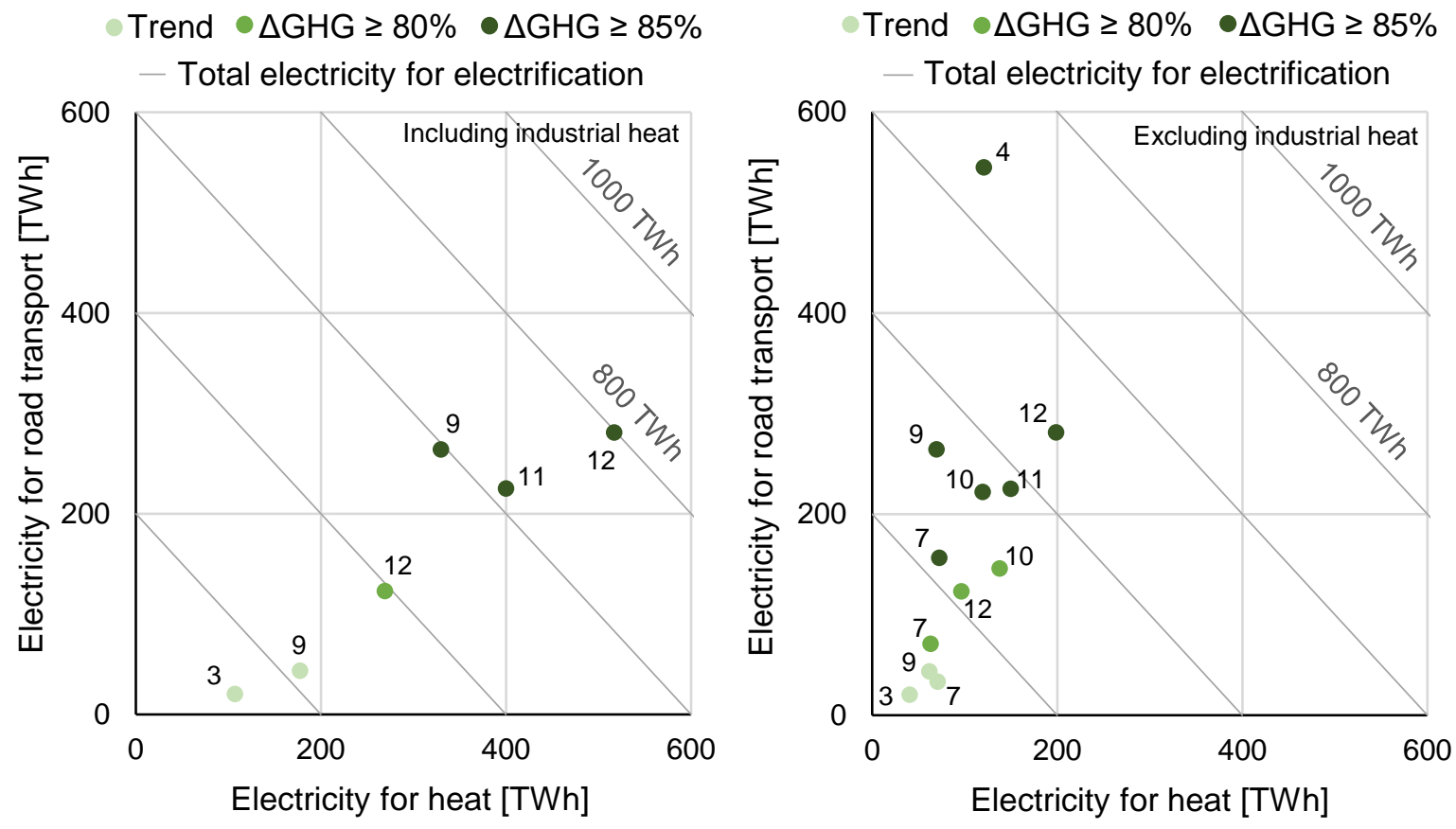

Figure 2: Electricity consumption for heat and road transport, with heat for industrial processes included (left) and excluded (right). The points are labelled with the study numbers from Table 1.

Across all scenarios that meet the emission reduction targets ( $\triangle \mathrm{GHG} \geq 80 \%$ and $\Delta \mathrm{GHG} \geq 85 \%$ ), the electricity for heat generation, which is consumed by electric heaters, electric heat pumps, and powerto-gas processes generating synthetic gases that are transformed into heat, is in the range of 269517 TWh [30] if heat for industrial processes is included (left plot) and in the range of 63-199 TWh [24, 30 ] if it is not (right plot). The electricity for road transport, which is consumed by battery electric vehicles, trolleys, and power-to-fuel (gaseous or liquid) processes generating synthetic fuels that are used for road transport, is between $71 \mathrm{TWh}$ [24] and $281 \mathrm{TWh}$ [30], except for one study, which reports as much as $545 \mathrm{TWh}[21]$ of electricity consumption for transport. The total electricity consumption for the electrification of both heat generation and road transport accounts for 392-798 TWh [30] and for 134-666 TWh [21, 24] if heat for industrial processes is included and if it is not, respectively. Note that this electricity consumption does not include the electricity consumption for non-heat applications in the sectors industry and buildings, which amounted to 399 TWh in 2015 [32]. 
Trend $\bullet \mathrm{GHG} \geq 80 \% \bullet \triangle \mathrm{GHG} \geq 85 \%$

- Total electricity for electrification

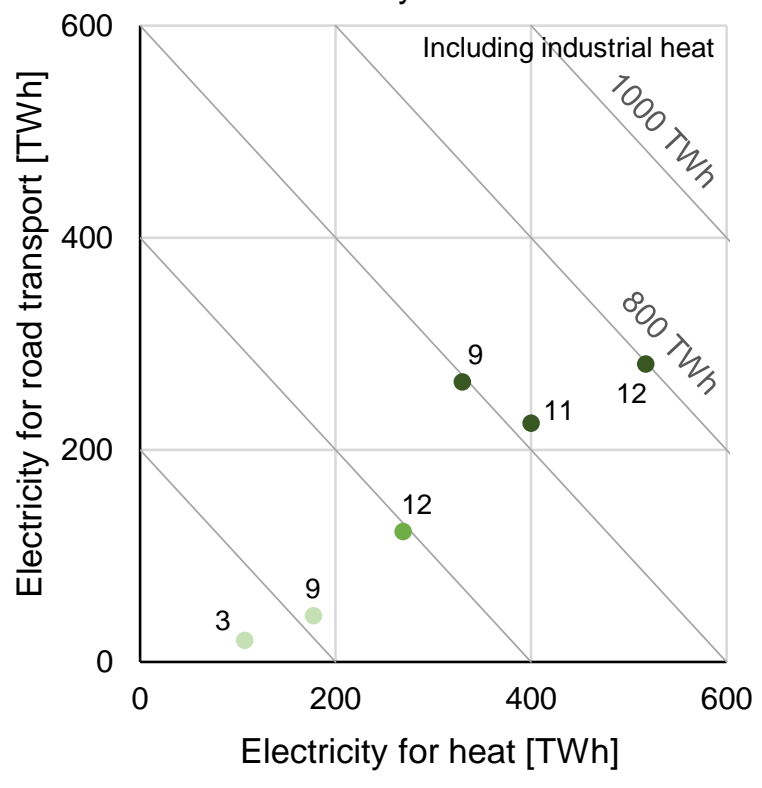

The different clusters in

- Trend $\bullet \triangle \mathrm{GHG} \geq 80 \% \bullet \triangle \mathrm{GHG} \geq 85 \%$

- Total electricity for electrification

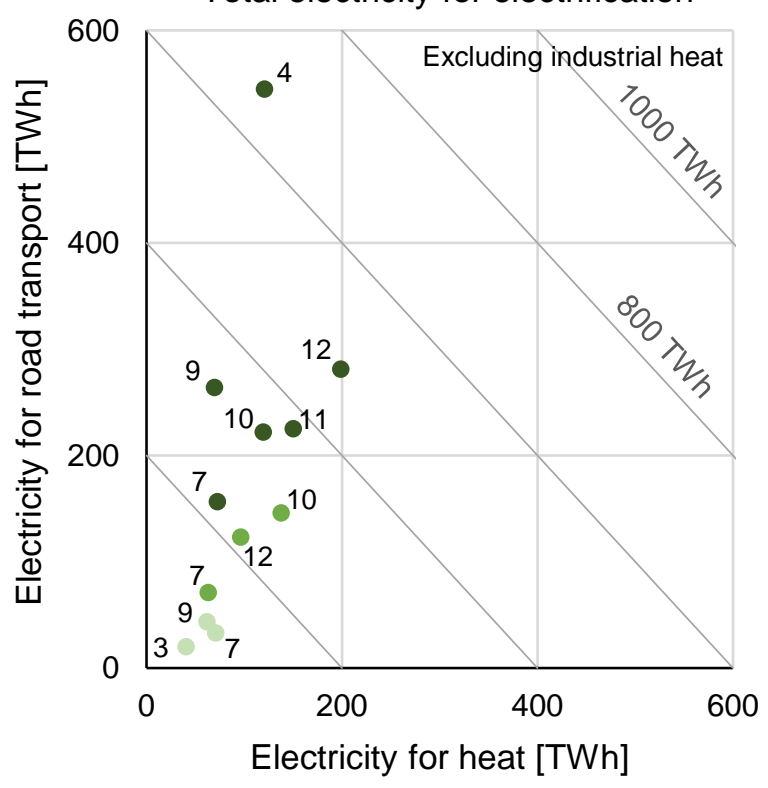

Figure 2 reveal that electrification is highly sensitive to GHG mitigation: the more emissions are to be reduced, the more electricity is consumed for the electrification of both heat generation and road transport. Of course, this additional electricity must be generated from carbon-free sources to have a positive effect on GHG emission. Put differently, the scenarios anticipate that additional GHG savings in heat generation and road transport are rather realized by decarbonised electricity generation than by other decarbonisation measures. This connection is very pronounced for road transport: in the right plot 
of
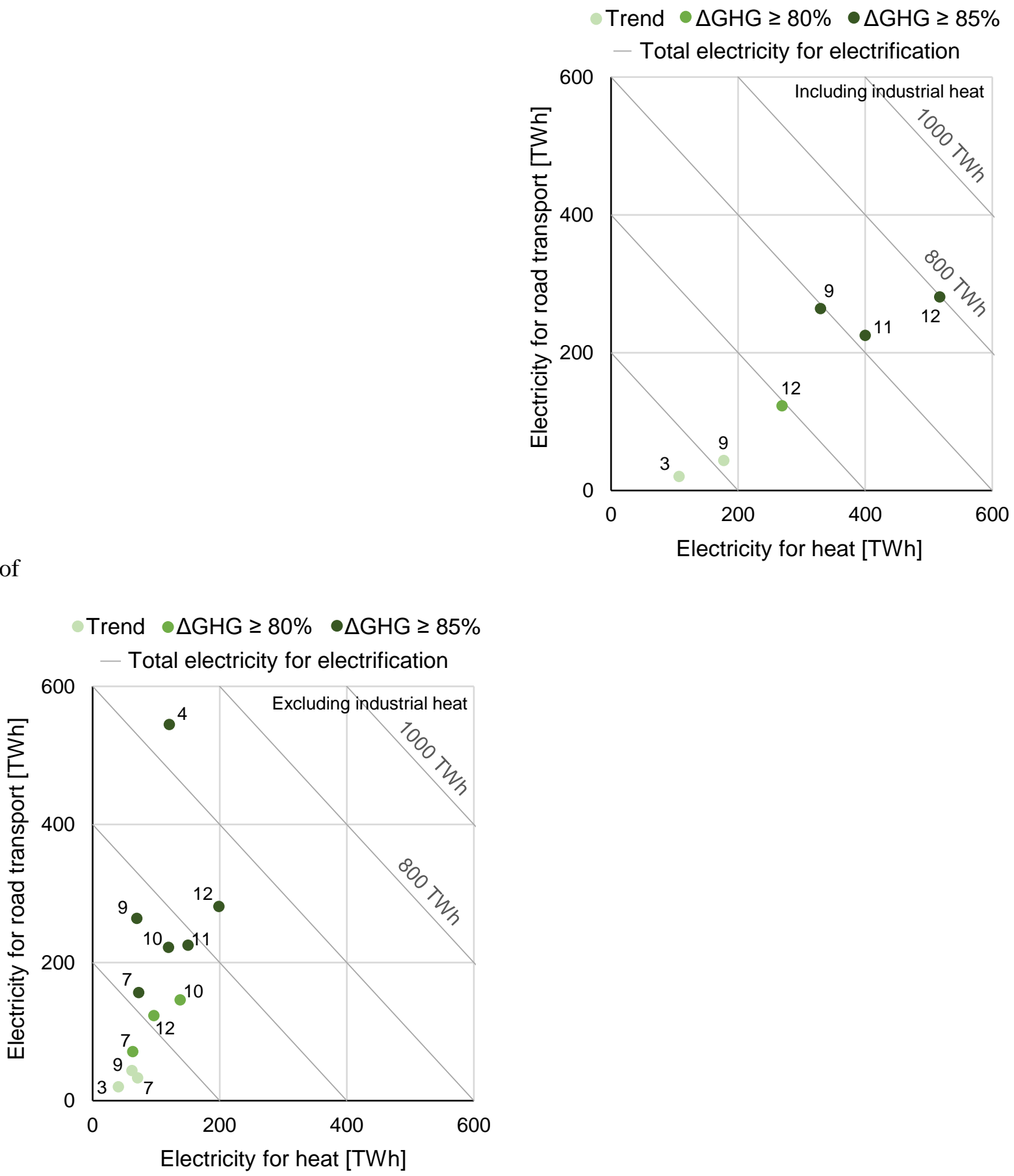

Figure 2, the electricity consumption is in the range of $71 \mathrm{TWh}[24]$ to $146 \mathrm{TWh}[28]$ in the " $\Delta \mathrm{GHG} \geq$ $80 \%$ " cluster, whereas it reaches 156 TWh [24] to 281 TWh [30] in the " $\Delta \mathrm{GHG} \geq 85 \%$ " cluster (or even $545 \mathrm{TWh}$ for the outlier UBA [21]). In contrast, the connection between GHG mitigation and the electricity consumption for heat in buildings is quite weak: the latter varies between 63 TWh [24] and $138 \mathrm{TWh}[28]$ in the " $\Delta \mathrm{GHG} \geq 80 \%$ " cluster and between $70 \mathrm{TWh}[26]$ and $199 \mathrm{TWh}[30]$ in the " $\Delta \mathrm{GHG}$ $\geq 85 \%$ " cluster. Apparently, electrification is of major importance for the reduction of GHG emissions from road transport, whereas it can partly be substituted by other decarbonisation options for the case of heat generation, e.g. by building retrofit or non-electric renewables (solar thermal and biomass). 
However, if heat for industrial processes is included in the analysis (left part of
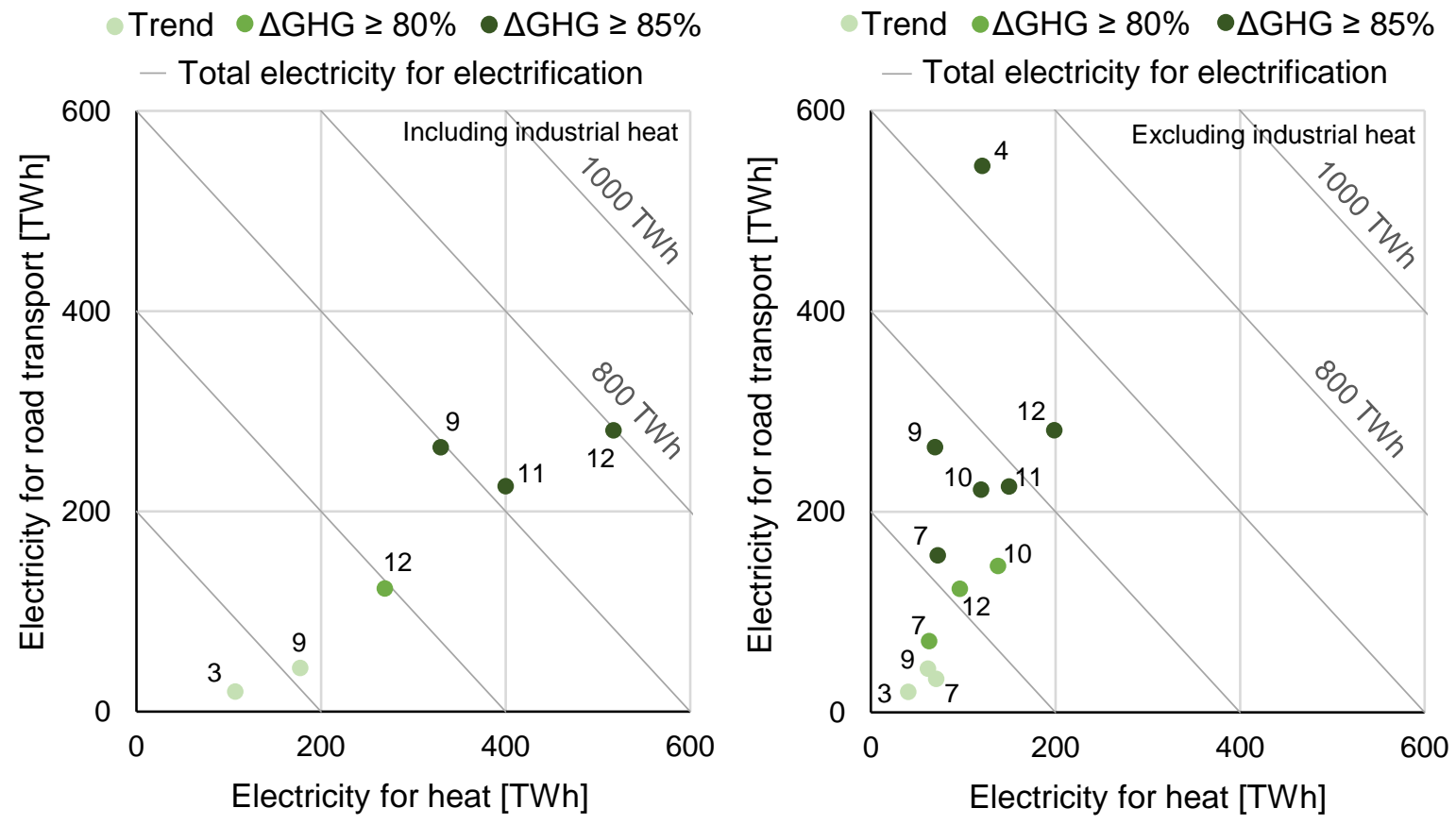

Figure 2), the connection between GHG mitigation and heat electrification becomes much more distinct, which is indicative of the fact that heat for industrial processes can hardly be decarbonised without renewable electricity.

- Trend $\bullet \Delta \mathrm{GHG} \geq 80 \% \bullet \Delta \mathrm{GHG} \geq 85 \%$

- Total electricity for electrification

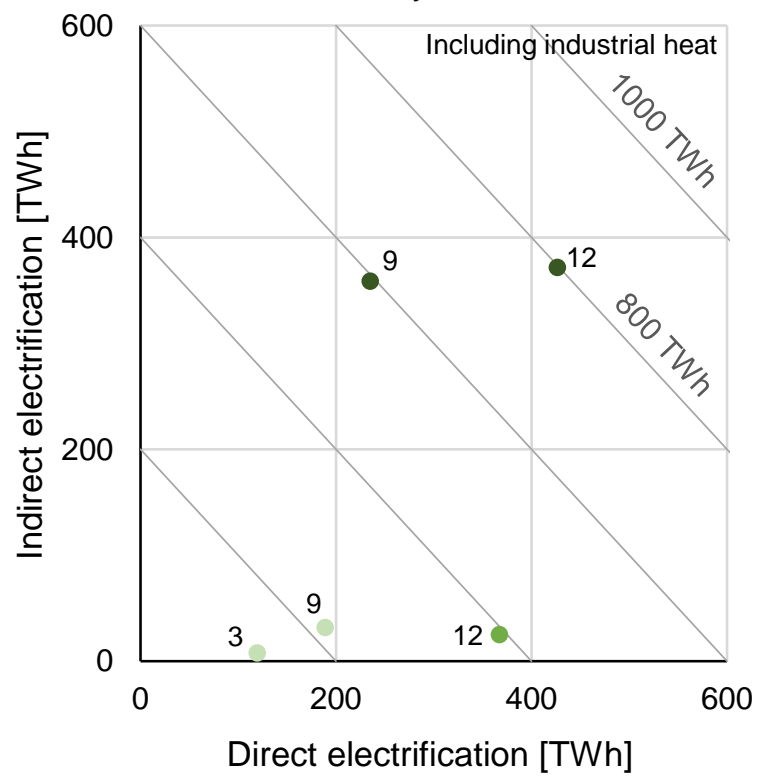

- Trend $\bullet \mathrm{GHG} \geq 80 \% \bullet \Delta \mathrm{GHG} \geq 85 \%$

- Total electricity for electrification

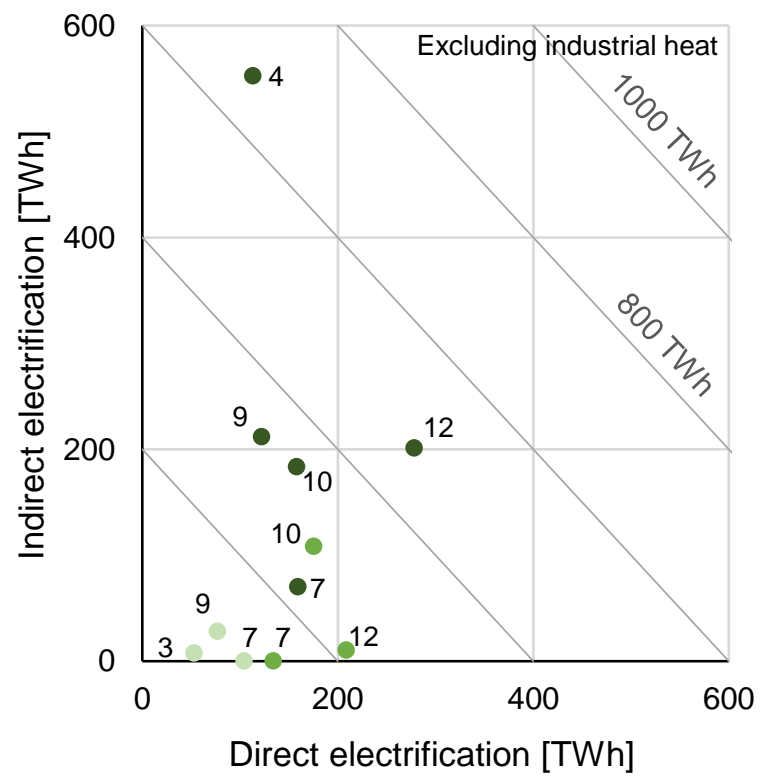

Figure 3 evaluates the electricity consumption for heat and road transport by the second dimension of our analysis: type of electrification. Thus, the electricity consumption for direct electrification and the 
electricity consumption for indirect electrification are displayed on the axes. As before, the total electricity consumption can be read from the contour lines.
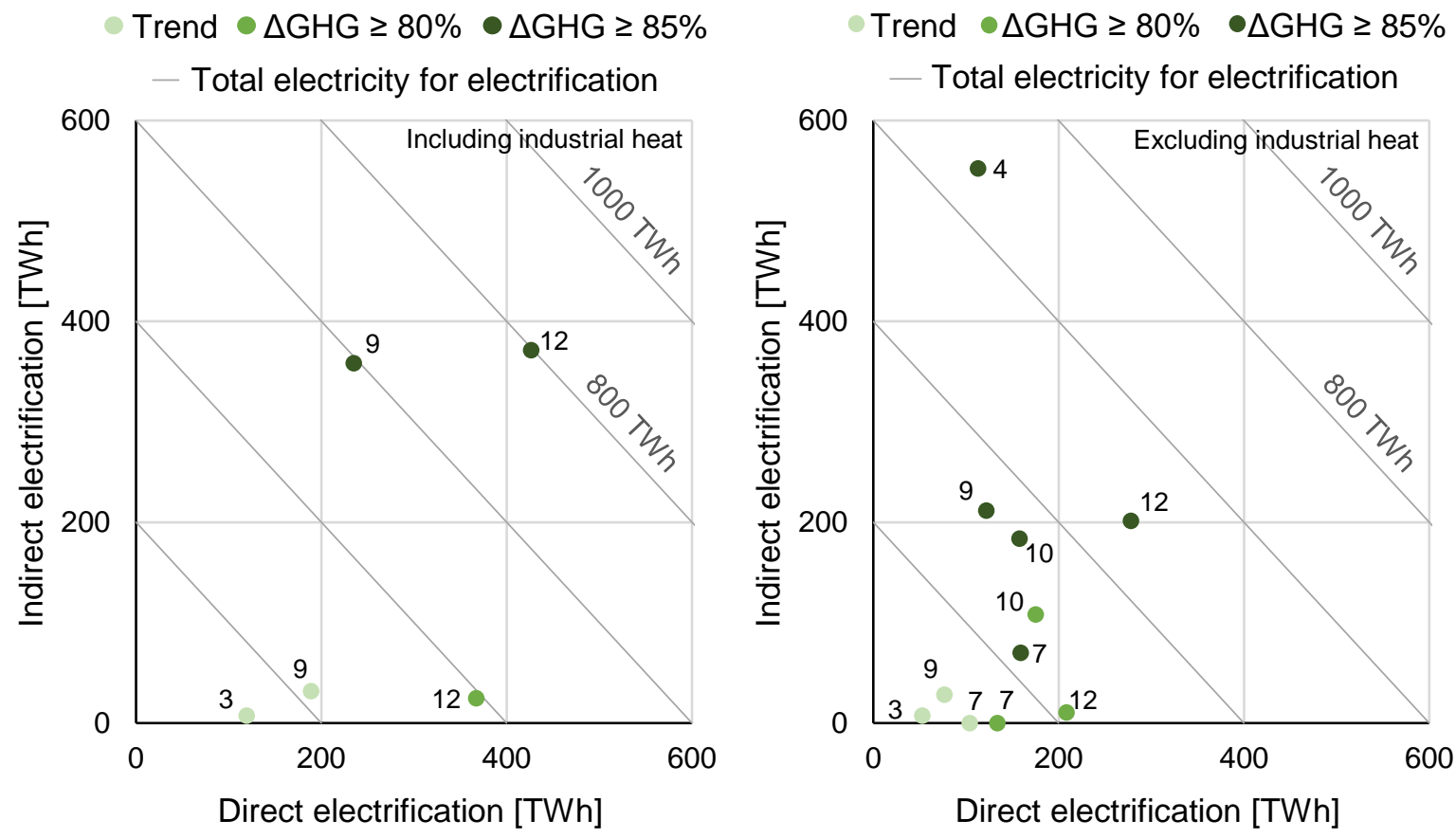

Figure 3: Electricity consumption for direct and indirect electrification, with heat for industrial processes included (left) and excluded (right). The points are labelled with the study numbers from Table 1.

For the scenarios meeting the emission reduction targets ( $\triangle \mathrm{GHG} \geq 80 \%$ and $\Delta \mathrm{GHG} \geq 85 \%$ ), it can be seen that the electricity consumption for indirect electrification varies in a much wider range than the electricity consumption for direct electrification, e.g. $0 \mathrm{TWh}$ [24] to $552 \mathrm{TWh}$ [21] as compared to 113 TWh [21] to $278 \mathrm{TWh}$ [30] when heat for industrial processes is excluded (right plot). This can possibly be explained by the low conversion efficiency of indirect electrification paths, which amplifies the electricity consumption for these.

Again, the clusters allow for drawing conclusions on the connection between GHG emission reductions and electrification. For the scenarios that reach the lower bound of the emission targets ( $\triangle \mathrm{GHG} \geq 80 \%$ ), the electricity consumption for direct electrification is significantly larger than the electricity consumption for indirect electrification. The fact that direct electrification is deployed first seems plausible in view of higher efficiencies of direct electrification paths. If emissions are reduced further ( $\triangle \mathrm{GHG} \geq 85 \%$ ), this primarily amplifies the amount of indirect electrification, which could be explained by the extended need for (long-term) storages to balance the electricity generation from variable renewables with consumption. 
Note that some studies consider the import of synthetic gases and that the foreign electricity consumption for the synthesis of these gases is included in the calculations above. Thus, part of the electricity consumption that we have identified does not affect the German electricity system but occurs abroad (e.g. Fraunhofer IWES/IBP [30]).

\subsection{Electrification of heat}

From the energy end-use perspective of heat generation, we analyse different electrification types: direct electrification, using electric heaters and electric heat pumps, and indirect electrification, using synthetic gases in gas heaters, gas heat pumps, and cogeneration plants. The results are depicted in
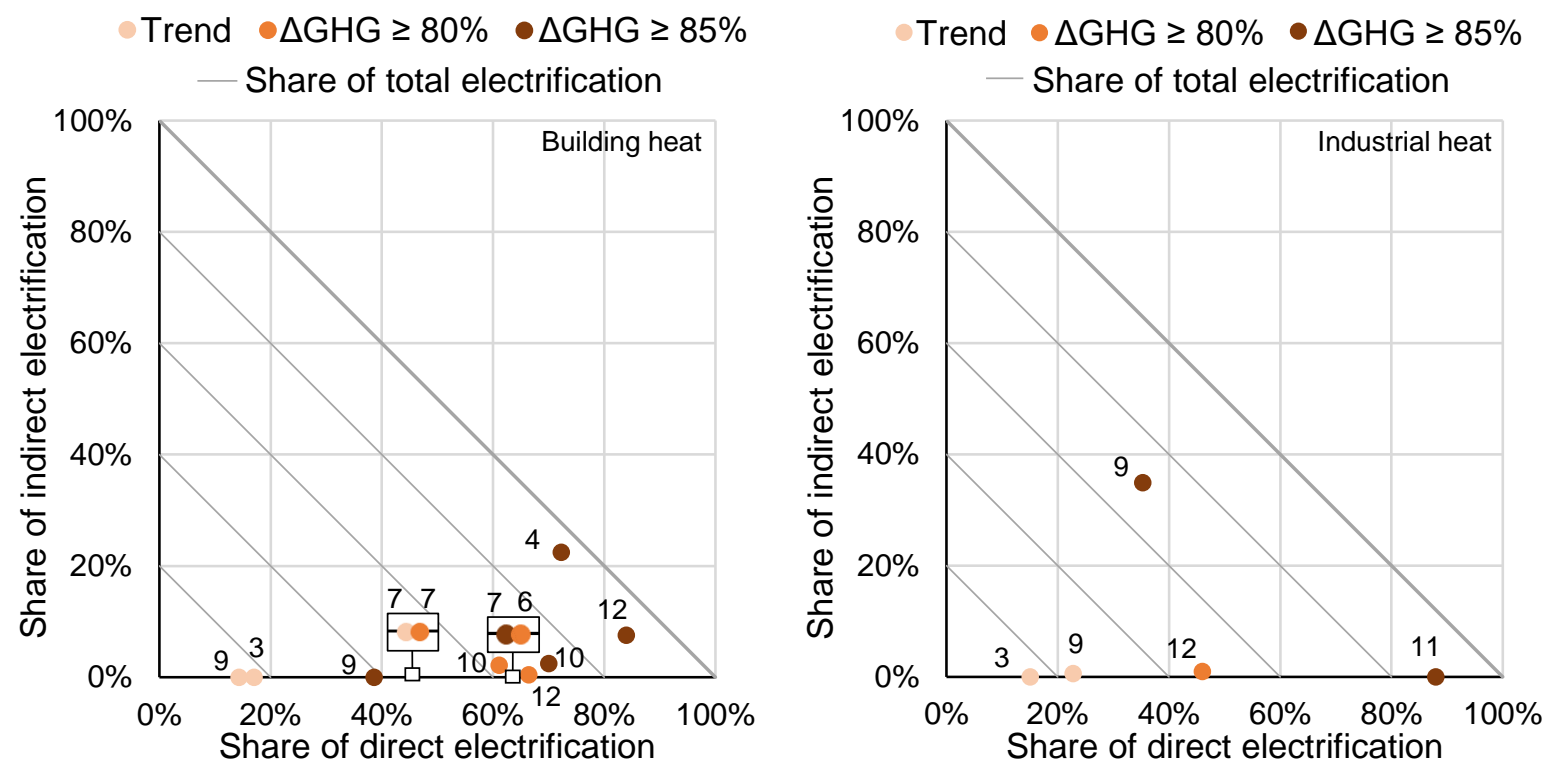

Figure 4, separated into heat for buildings (left plot) and heat for industrial processes (right plot). In all scenarios that fulfil the GHG emission reduction target $(\triangle \mathrm{GHG} \geq 80 \%$ and $\Delta \mathrm{GHG} \geq 85 \%$ ), a considerable amount of heat is generated by direct electrification, more precisely $39-84 \%$ of heat for buildings [26, 30] and 35-88\% of heat for industrial processes [26, 29]. In contrast, the share of indirect electrification is limited to $22 \%$ [21] for the case of buildings and to $35 \%$ [26] for the case of industrial processes. 

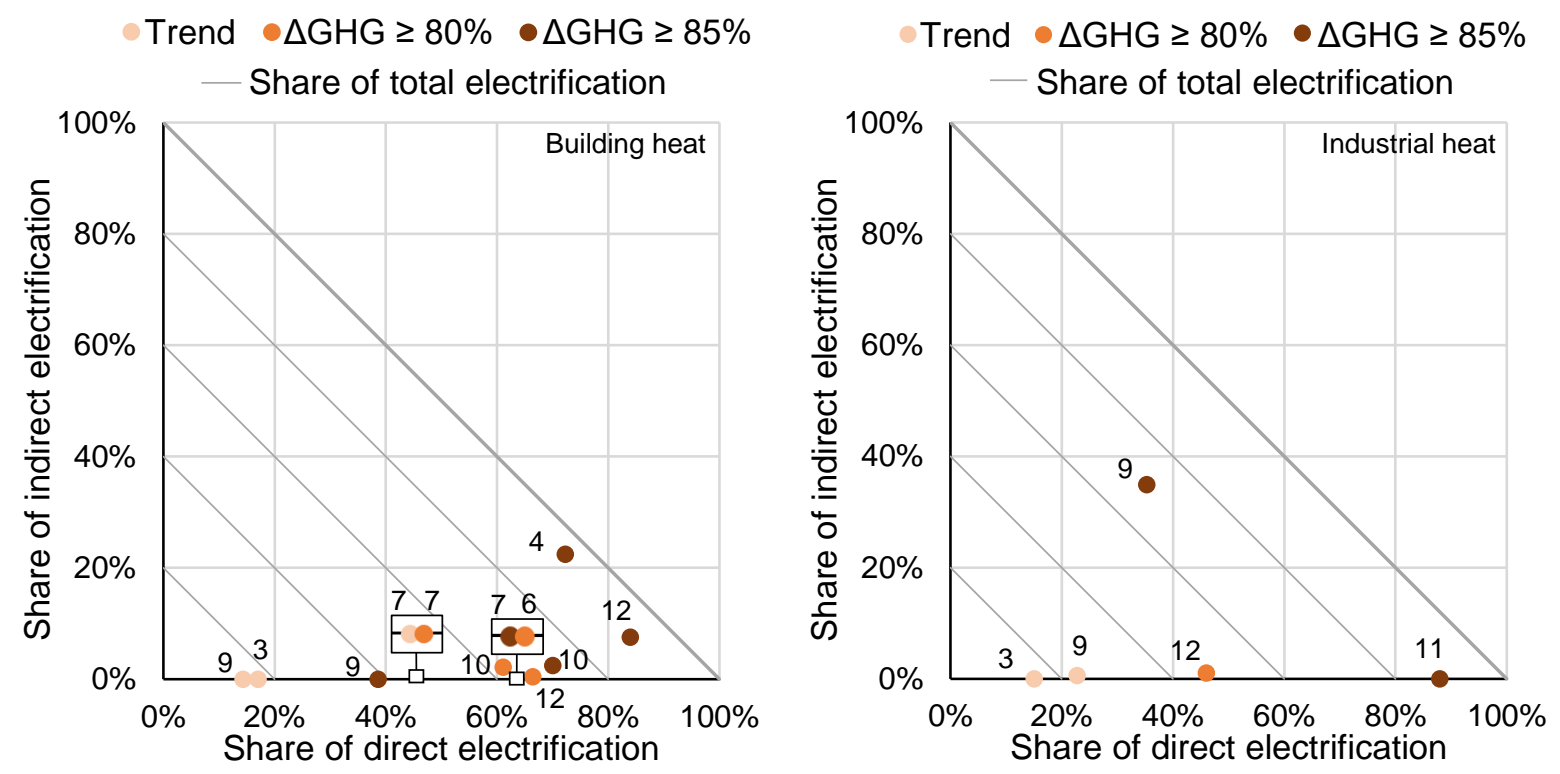

Figure 4: Share of direct and indirect electrification and the share of total electrification (grey lines) related to useful energy in heat for buildings (left) and heat for industrial processes (right).

The points are labelled with the study numbers from Table 1.

There is a slight tendency that large shares of total electrification (which can be read from the grey contour lines) coincide with extensive emission reductions, but there is a wide variance within the different GHG clusters: $14 \%$ [26] to 45\% [24] of total electrification occurs in the "Trend" cluster, 45\% [24] to $66 \%$ [30] in the " $\Delta \mathrm{GHG} \geq 80 \%$ " cluster, and $39 \%$ [26] to $94 \%$ [21] in the " $\Delta \mathrm{GHG} \geq 85 \%$ " cluster. The variance can be traced back to the role of other emission reduction options such as efficiency, which reduces the useful energy demand, and the use of non-electric renewables such as solar thermal and biomass. Obviously, various studies do not agree on the optimal mix of different decarbonisation options, particularly in the context of extensive GHG mitigation, where the variance of the electrification share is the largest. Note that significant shares of indirect electrification only occur in some of the scenarios where GHG emissions are reduced by more than $85 \%$, which could be explained by its unfavourable low efficiency but the need for long-term energy storage when decarbonisation proceeds.

Figure 5 breaks down the share of direct electrification into electric heaters and electric heat pumps. For heat in buildings, one can notice that electric heat pumps dominate the electrification with a share of up to $75 \%$ [30] and a minimum of $27 \%$ [26], while the electric heater share is maximally $12 \%$ [26]. However, electric heaters are the dominant technology for the heat electrification of industrial processes, whereas electric heat pumps for industrial processes are only present in one scenario. 

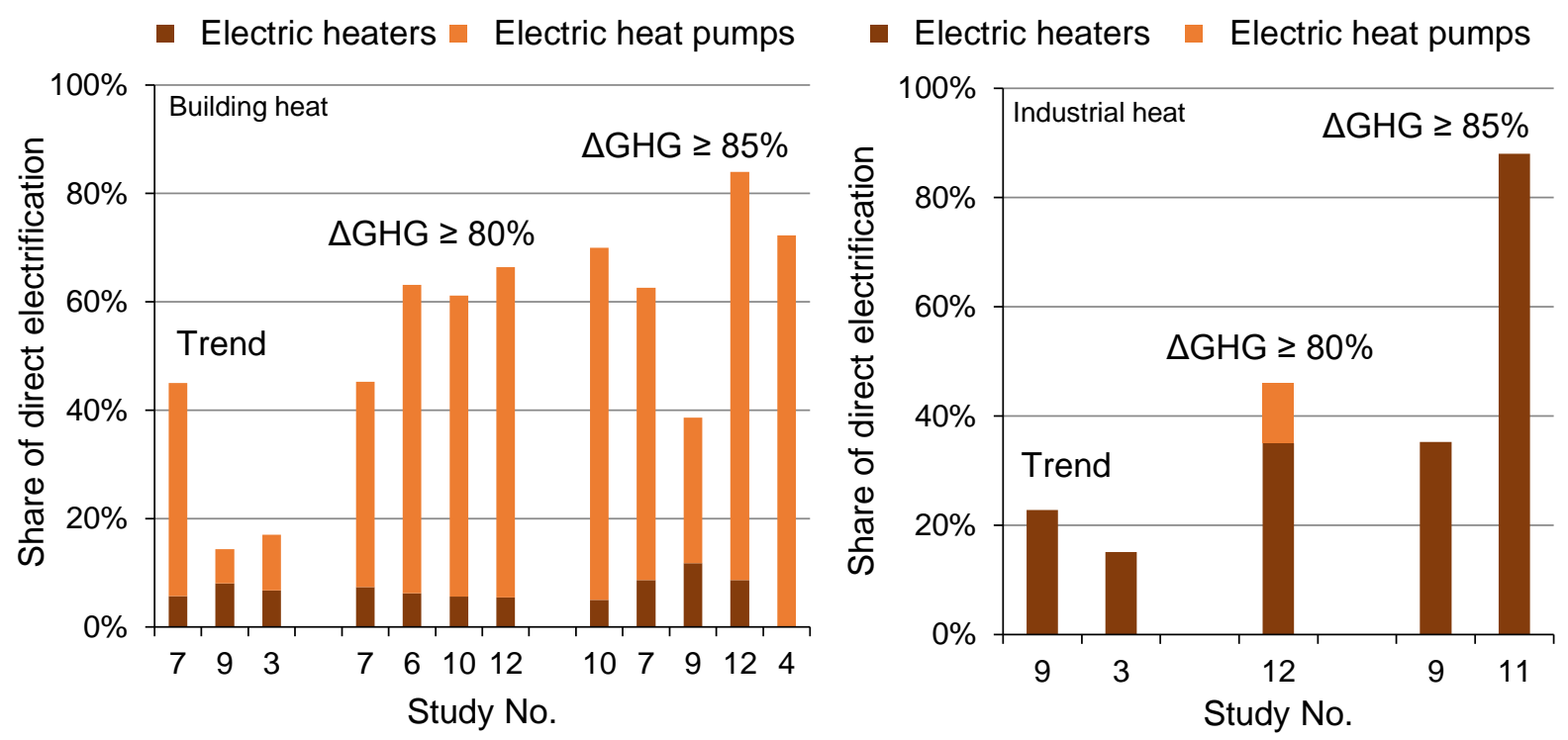

Figure 5: Share of direct electrification related to useful energy in building heat (left) and industrial heat (right).

\subsection{Electrification of road transport}

From the energy end-use perspective of road transport, we compare direct electrification, using battery electric vehicles and trolleys, with indirect electrification, using synthetic hydrogen in fuel cell electric vehicles and synthetic methane or liquids in internal combustion engine vehicles. Figure 6 presents the results of our analysis. 

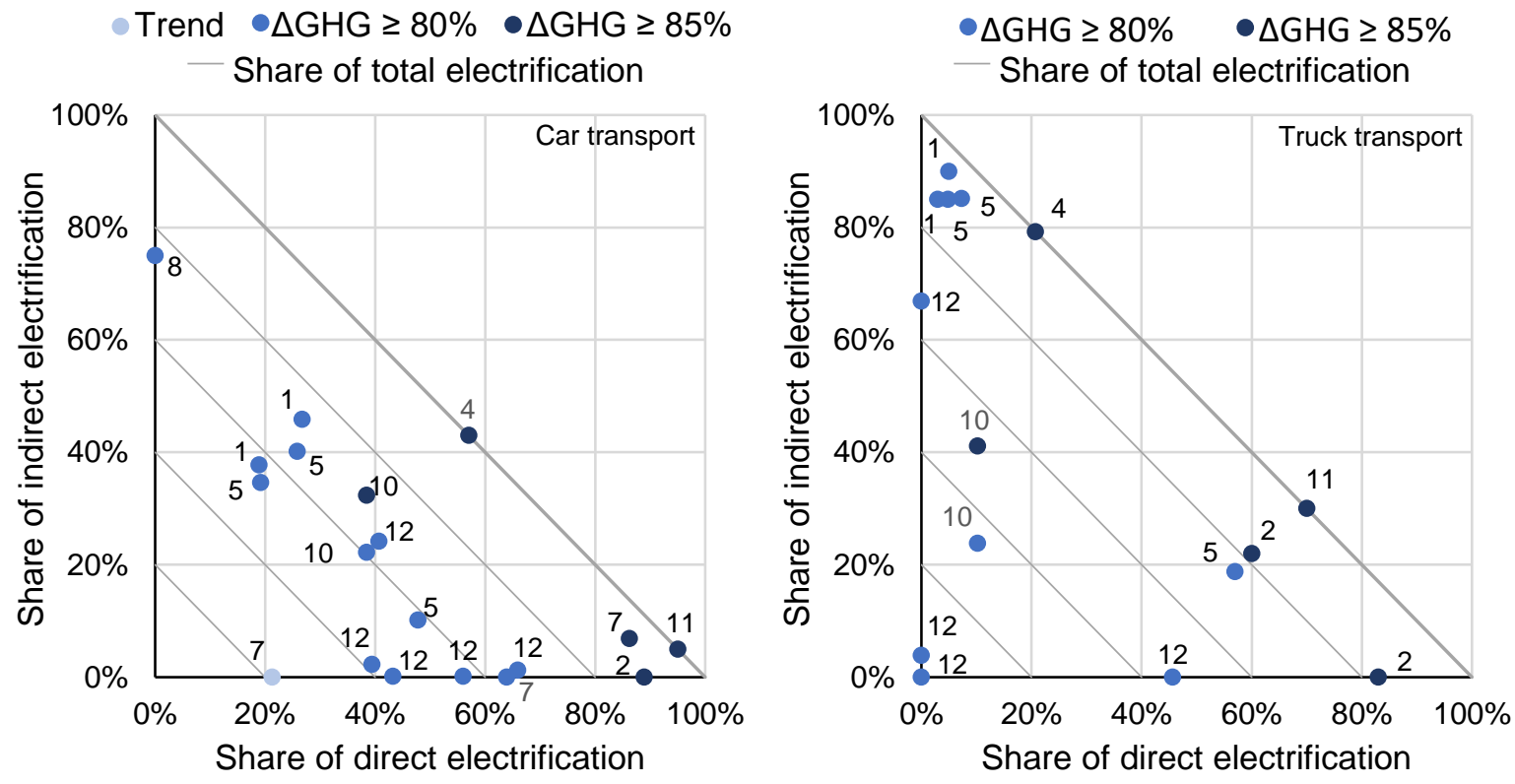

Figure 6: Share of direct and indirect electrification and the share of total electrification (grey lines) related to useful energy in car transport (left) and in truck transport (right).

The points are labelled with the study numbers from Table 1.

Regarding car transport (left plot), the different scenario clusters can be clearly differentiated from each other with respect to the share of total electrification (which can be read from the grey contour lines): in the scenarios that reach the lower bound of the emission reduction target ( $\triangle \mathrm{GHG} \geq 80 \%$ ), it is in the range of $41 \%$ [30] to $75 \%$ [25], whereas further GHG reductions ( $\triangle \mathrm{GHG} \geq 85 \%$ ) lead to total electrification shares of 70\% [28] to 100\% [21, 29]. Apparently, other decarbonisation options, namely efficiency and biofuels, can substitute electrification and enable successful GHG mitigation at car transport electrification shares as low as $40 \%$ but, compared to heat generation in buildings, the limits of these substitutes are assessed more homogeneously across various scenarios. Within the identified boundaries of total electrification, however, the scenarios in each cluster disagree on the dominant type of car transport electrification, even though a tendency towards direct electrification of cars can be observed. Except from one study that ex ante focuses on indirect electrification only [25], the share of direct electrification is in the range of $19 \%[18,22]$ to $66 \%[30]$ in the " $\Delta \mathrm{GHG} \geq 80 \%$ " cluster and in the range of $38 \%$ [28] to $95 \%$ [29] in the " $\Delta \mathrm{GHG} \geq 85 \%$ " cluster, and the share of indirect electrification varies between $0 \%$ and $46 \%$ [18] for both clusters. 
For the case of truck transport (right plot in
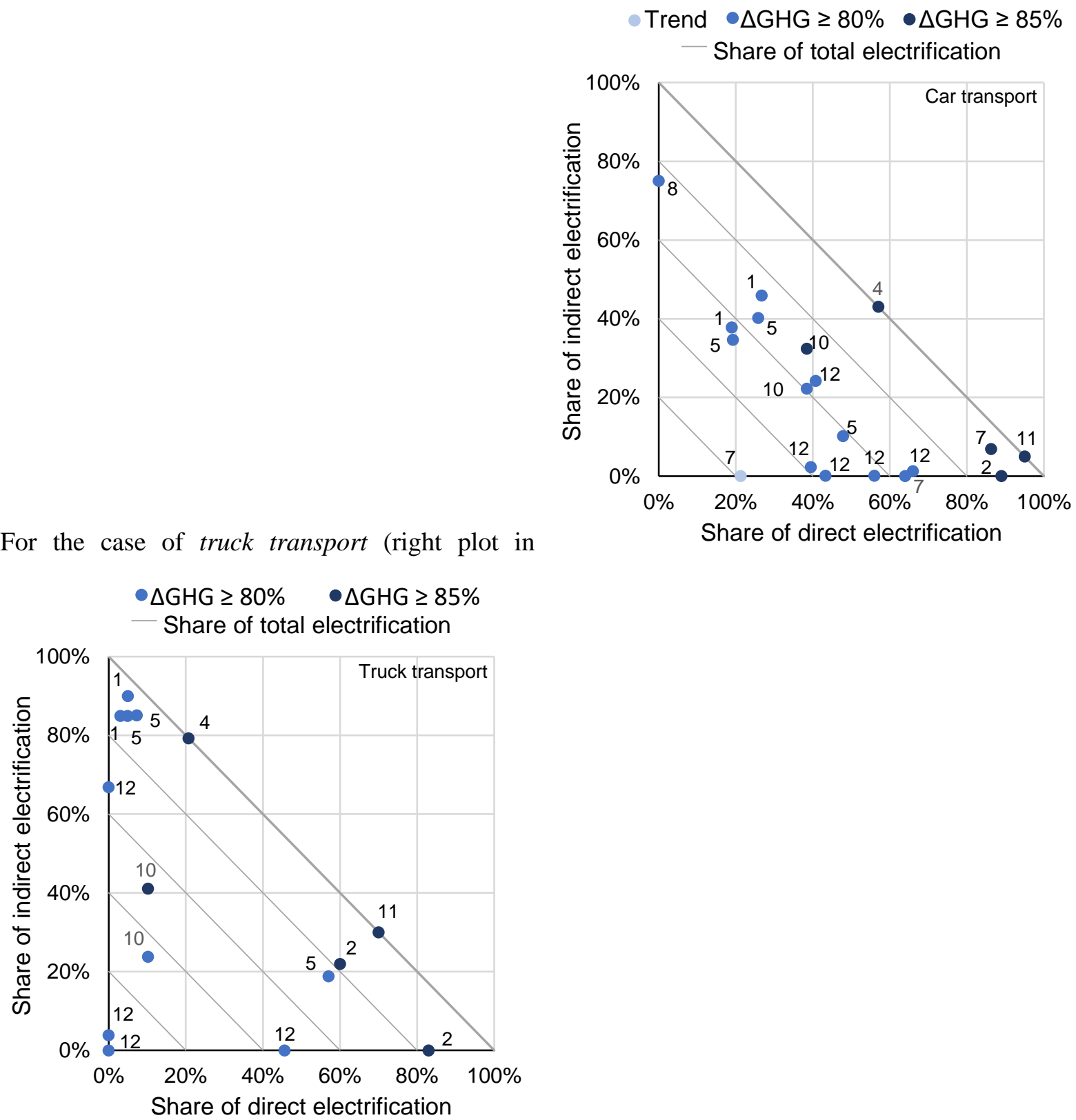

Figure 6), two clusters of scenarios can be distinguished and related to one critical assumption: the five scenarios with mainly direct electrification consider overhead lines for truck transport and the others do not (cf. subsection 4.4). The share of total electrification is also very different in the scenarios reviewed. In the " $\Delta \mathrm{GHG} \geq 80 \%$ " cluster, some scenarios feature no or little electrification [30], while others include up to $95 \%[18,21,29]$ of electrified truck transportation. If emissions are to be reduced beyond $85 \%$, however, all scenarios comprise at least $51 \%$ of total electrification. The high variance of total electrification can be explained by the fact that, in some scenarios, truck transport is either decarbonised by non-electric renewables (biofuels) or increased efficiency and that, in other scenarios, the degree of decarbonisation in the truck sector is rather low such that trucks make a major contribution to the remaining, non-mitigated GHG emissions [30]. 

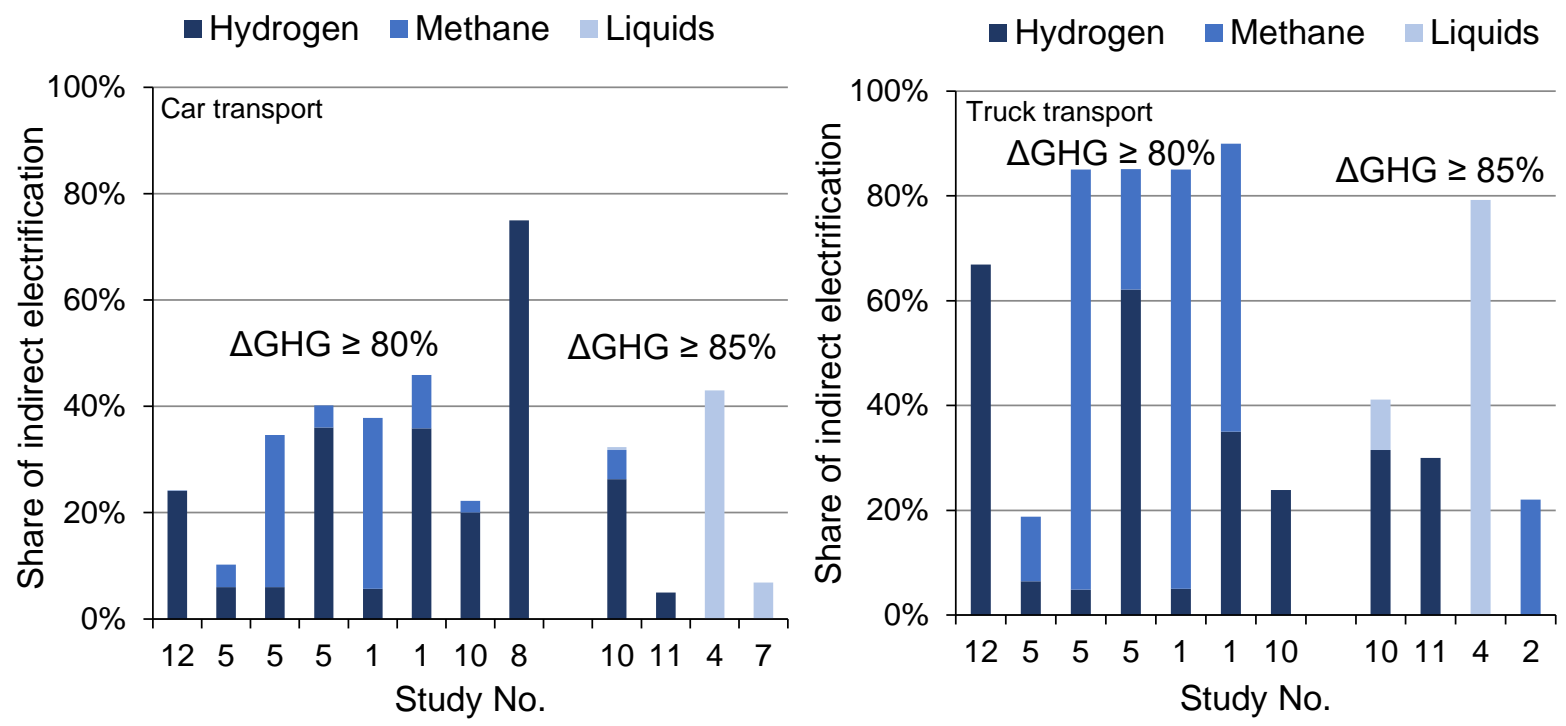

Figure 7 depicts the share of synthetic fuels for car and truck transport. The indirectly electrified car transport is dominated by synthetic hydrogen, which poses as major fuel in seven out of ten scenarios, where synthetic fuels supply more than $20 \%$ of total car transport (up to $75 \%$ for the case of Robinius [25]). In contrast, scenarios with a high share of methane are more likely to be found in the truck segment. A possible explanation for this is that methane can be used in conventional internal combustion engines while the higher demand for fuel due to the higher weight of trucks would require larger and thus heavier fuel cells if one wanted to fuel truck transport with hydrogen. Interestingly, both car and truck transport, synthetic liquids are only considered for $\Delta \mathrm{GHG} \geq 85 \%$.
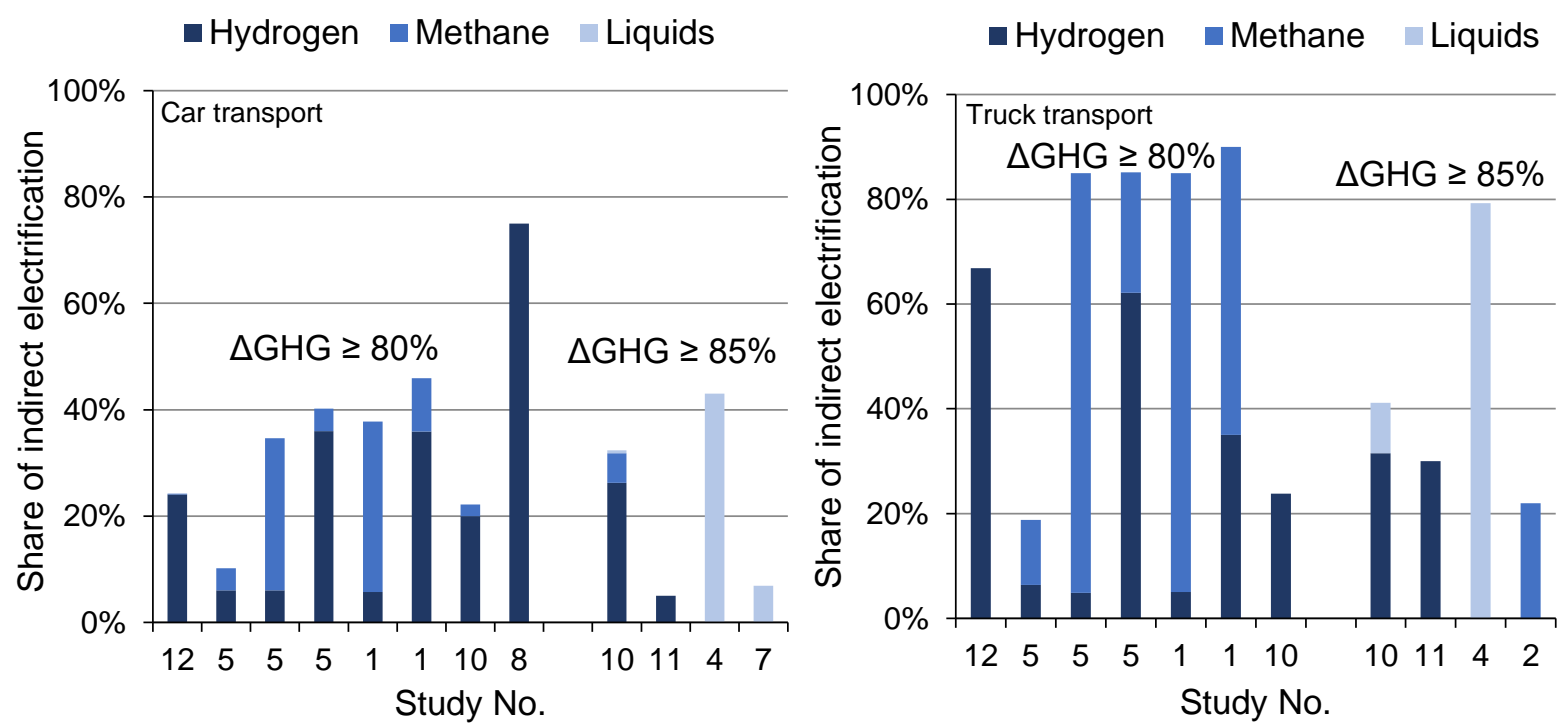

Figure 7: Share of synthetic fuels related to useful energy in car transport (left) and truck transport (right). 


\subsection{Electrification technologies}

To substantiate the preceding review of the scenario results, this subsection sheds a light on the underlying assumptions on technological development.

Technologies for synthesising fuels from electricity and for their distribution are key to all indirect electrification paths. Focusing on the main fuels, hydrogen and methane, Table 2 summarises the assumed conversion efficiencies for all studies that provide this information. The efficiency assumptions on the power-to-hydrogen conversion, i.e. electrolysis, vary substantially between $65 \%$ [22] and $80 \%$ [28], which can be traced back to (implicit) assumptions on the availability of the more efficient yet commercially unproved high-temperature electrolysis (see, e.g., Oeko-Institut [19]). The power-tomethane conversion efficiency is expected to range from 53\% [19] to 64\% [28]. Here, the uncertain efficiency of electrolysis multiplies with the uncertain efficiency of methanation, which is in addition mainly dependent on the type of $\mathrm{CO}_{2}$ source. The values in Table $2 \mathrm{imply}$ that a concentrated $\mathrm{CO}_{2}$ source is available and thus risk being worse if this was not the case. Regarding the large-scale distribution of hydrogen, an unprecedented and thus technological uncertain infrastructure would be needed - based either on distributed or on central pipeline systems. In contrast, synthetic methane could be distributed and stored using the existing technological mature natural gas infrastructure.

Table 2: Conversion efficiencies for fuel syntheses assumed in the studies reviewed.

\begin{tabular}{llcc} 
No. & Reference & Power-to-hydrogen & Power-to-methane \\
\hline \hline 1 & DLR et al. [18] & $76 \%$ & $61 \%$ \\
\hline 2 & Oeko-Institut [19] & $70 \%$ & $53 \%$ \\
\hline 4 & UBA [21] & $72 \%$ & $58 \%$ \\
\hline 5 & DLR et al. [22] & $65 \%$ & $56 \%$ \\
\hline 8 & Robinius [25] & $70 \%$ & - \\
\hline 10 & Palzer [28] & $80 \%$ & $64 \%$ \\
\hline
\end{tabular}

The perspectives of building heat generation technologies are relatively clear. Combustion and electric boilers are fully developed, and their efficiency is assumed to stagnate around $95 \%$ and $98 \%$, respectively (e.g., Heilek [23]). Furthermore, electric heat pumps are a proven technology that is considered in all studies (Table 3) but with increasing efficiencies ranging from 4 [23] to 5 [29]. However, these efficiency gains are mainly due to improved heat sources (ground instead of air) and heat sinks (low-temperature heating in well-isolated houses) rather than being the result of heat pump technology improvement. Gas heat pumps are considered only in four out of eight studies but even in these, they do not play a major role if any (e.g., Fraunhofer IWES et al. [31]).

Despite only few studies are explicitly discussing industrial heat, they disagree on its technological outlook. While Quaschning [29] focuses on electric heaters, Oeko-Institut and Fraunhofer ISI [24] and Fraunhofer IWES et al. [31] expect new heat pumps to be able to provide heat at temperature levels up 
to $100^{\circ} \mathrm{C}$ and more thus becoming relevant for some industrial processes. In contrast, Nitsch [26] assumes hydrogen-based combined heat and power to be available for industry use.

Table 3: Efficiency (annual coefficient of performance) and consideration of building heat technologies in 2050, as assumed in the studies reviewed.

\begin{tabular}{llcc} 
No. & Reference & Electric heat pumps & Gas heat pumps \\
\hline \hline 3 & Prognos et al. [20] & 4,29 & Considered \\
& TREND [TARGET] & {$[4,97]$} & \\
\hline 4 & UBA [21] & Considered & Not considered \\
\hline 6 & Heilek [23] & 4,0 & Not considered \\
\hline 7 & Oeko-Institut and & Considered & Not considered \\
& Fraunhofer ISI [24] & & \\
\hline 9 & Nitsch [26] & Considered & Not considered \\
\hline 10 & Palzer [28] & Considered & Considered \\
\hline 11 & Quaschning [29] & Up to 5 & 2 \\
\hline 12 & Fraunhofer IWES et al. & Air: 3,8 & 1,8 \\
& {$[31]$} & Ground: 4,4 & \\
\hline
\end{tabular}

For the main car transport technologies, Table 4 provides an overview of the assumed efficiency increase in 2050 as compared to the 2010s. Even though combustion engine vehicles are a mature technology, all studies assume substantial efficiency gains from $27 \%$ [22] to $64 \%$ [19], which reduces the demand for synthetic and bio fuels and the emissions of the remaining fossil-fuelled cars. According to Oeko-Institut and Fraunhofer ISI [24], the lower bound of this wide range can be associated with the current technological trend and the upper bound implies additional efforts. In both cases, not only the engine but also the weight and aerodynamics of the car need to be refined. Ranging from 18\% [24] to $39 \%$ [19], the assumed efficiency increase of battery electric vehicles is likewise variable yet generally lower, which can be explained by the electric engine being already more efficient. Besides efficiency gains, some studies explicitly assume massive cost reductions (-55\% in Palzer [28] and cost parity with conventional technologies in DLR et al. [18] and Oeko-Institut [19]) and increased ranges (250 km in UBA [21] and $300 \mathrm{~km}$ in Oeko-Institut and Fraunhofer ISI [24]). All these improvements boil down to massive innovations in existing lithium-ion battery technology or even the breakthrough of post-lithiumion technology [19]. Information on efficiency improvements of fuel cell electric vehicles is scarce in the studies reviewed, and some studies do not at all consider this technology in their scenarios (UBA [21] and Oeko-Institut and Fraunhofer ISI [24]). Frequently discussed challenges are the robustness and durability of the technology, but several studies assume these to be overcome at competitive prices (e.g., DLR et al. [18]). Note that hybrid electric vehicles, which are a combination of the previously discussed combustion engine and battery electric technologies, play a major role in many scenarios. 
Table 4: Efficiency gains and consideration of car transport technologies in 2050, as assumed in the studies

reviewed.

\begin{tabular}{llccc} 
No. & Reference & $\begin{array}{c}\text { Combustion } \\
\text { engine vehicles }\end{array}$ & $\begin{array}{c}\text { Battery } \\
\text { electric vehicles }\end{array}$ & $\begin{array}{c}\text { Fuel cell } \\
\text { electric vehicles }\end{array}$ \\
\hline \hline 2 & Oeko-Institut [19] & $54-64 \%$ & $39 \%$ & Considered \\
\hline 3 & Prognos et al. [20] & $40 \%$ & $27 \%$ & $21 \%$ \\
\hline 5 & DLR et al. [22] & $27-30 \%$ & $27 \%$ & $28 \%$ \\
\hline 7 & Oeko-Institut and Fraunhofer & $30-36 \%$ & $18 \%$ & Not considered \\
& ISI [24] TREND [TARGET] & {$[49-57 \%]$} & {$[31 \%]$} & \\
\hline 12 & Fraunhofer IWES et al. [31] & $37-30 \%$ & Considered & Considered \\
\hline
\end{tabular}

Concerning truck transport, technological alternatives to the combustion engine are yet at an even earlier stage than for car transport. Against this background, is not surprising that electric vehicles with batteries, fuel cells or overhead wires are heterogeneously considered in the studies reviewed (Table 5). Interestingly, none of these alternative truck technologies is included in more than five out of eight studies, and only one study [21] neglects them all but assumes instead an efficiency gain as high as 50\% in conventional technologies. In other words, all scenarios rely on major yet different technological breakthroughs in the truck segment.

Table 5: Efficiency gains and consideration of truck transport technologies in 2050, as assumed in the studies reviewed.

\begin{tabular}{llcccc} 
& & Combustion & \multicolumn{3}{c}{ Electric vehicles with } \\
\cline { 3 - 5 } No. & Reference & engine vehicles & Batteries & Overhead wires & Fuel cells \\
\hline \hline 1 & DLR et al. [18] & Considered & Not considered & Not considered & Considered \\
\hline 2 & Oeko-Institut [19] & $30-40 \%$ & $16 \%$ & Considered & Not considered \\
\hline 3 & Prognos et al. [20] & $15-30 \%$ & $29 \%$ & Not considered & Not considered \\
\hline 4 & UBA [21] & $50 \%$ & Not considered & Not considered & Not considered \\
\hline 5 & DLR et al. [22] & $31-36 \%$ & Not considered & Considered & Considered \\
\hline 7 & Oeko-Institut and Fraunhofer & $30 \%$ & Considered & Not considered & Not considered \\
& ISI [24] TREND [TARGET] & & & [Considered] & \\
\hline 10 & Palzer [28] & Considered & Considered & Not considered & Considered \\
\hline 11 & Quaschning [29] & Considered & Not considered & Considered & Not considered \\
\hline 12 & Fraunhofer IWES et al. [31] & $31-34 \%$ & Considered & Considered & Considered \\
\hline
\end{tabular}

The degree of technological uncertainty is reflected in the heterogeneity of the electrification scenarios. For building heat, the technological dominance of heat pumps as an efficient and proven technology explains the scenarios clearly favouring direct electrification. Regarding car transport and industrial heat, technologies and scenarios become more divers, even though there seems to be a consensus on the availability and a corresponding minimum level of battery electric cars and electric process heaters. The immaturity of various alternative truck technologies is in line with the wide scenario range. Particularly, as discussed above, overhead wires seem to be a necessary condition to increase the direct electrification share for trucks beyond $20 \%$. 


\section{CONCLUSION AND POLICY IMPLICATIONS}

This scenario review demonstrates the paramount role of further end-use electrification for successful GHG mitigation in the German energy system by 2050. From our findings, we can draw at least five conclusions that are relevant for energy stakeholders:

1. Due to an intensified end-use electrification, the electricity consumption for heat and road transport in Germany is expected to rise to $400-800$ TWh by 2050 . Within this range, one driver of the electricity consumption that we identified is the targeted level of GHG emission reduction: The more the emissions are to be reduced, the more fossil fuels in the energy enduse sectors are expected to be substituted by renewable electricity. Policy makers should consider this additional need for renewable electricity when planning capacity expansion and focus on maintaining the high social acceptance of the energy transition, which is crucial to enable further growth of wind and solar electricity.

2. We have shown that electricity is expected to supply $40-95 \%$ of heat generation in Germany by 2050. Our results indicate that building heat electrification will occur mainly directly and can partly be substituted by energy efficiency and non-electric renewables (solar thermal and biomass), which explains the wide range of the results. Few studies explicitly include industrial heat, yet revealing larger technological uncertainty, e.g. concerning the availability of high temperature heat pumps and hydrogen-fuelled combined heat and power. The electricity consumption for heating can be highly variable and imply major challenges for the electricity system balance if no demand side management is applied [12,34]. Therefore, while supporting alternative decarbonisation measures to minimize the residual need for electrification, energy regulation should pave the way for system-friendly direct heat electrification. For example, electric heaters and heat pumps can be operated more flexibly if combined with thermal storages.

3. Electrification is likewise expected to make up 40-100\% of road transport in Germany by 2050. The variance of the electrification level can partly be traced back to the assumed GHG mitigation target: the more the emissions are to be reduced, the more road transport is expected to be electrified. The scenarios reviewed show no clear preference whether to directly or indirectly electrify road transport. Whereas at least $20 \%$ of car transport are expected to rely on battery electric vehicles, the fate of the remaining car transport seems to be unclear and not least related to technological innovation: further battery electric vehicles need improved battery technology and hydrogen fuel cell electric vehicles depend on a hydrogen infrastructure. Truck transport scenarios reflect the even more uncertain truck technology outlook in terms of very 
heterogeneous degrees and types of electrification as well as, for the indirect option, the synthetic fuels to use. This is highly relevant to policy makers as financial incentives, with or without preference for certain technologies, and infrastructure programmes are required for the large-scale development of both battery electric and hydrogen mobility $[35,36]$. Policy makers should be aware of the variety of road transport scenarios, particularly because the transport sector is characterized by strong "lock-in" effects, i.e. positive feedbacks on a selected technology even though it might be suboptimal [37].

4. Even though the results of various energy scenarios reveal a clear electrification trend, the exact level and, at least for the transport sector, the portfolio of electrification vary widely. The variations certainly reflect the intrinsic uncertainty of the energy future by 2050 , which can partly be traced back to uncertain technological development. The range of possible futures may even exceed that of the scenarios reviewed because, just as decision makers in the industry often fail to anticipate disruptive technologies [38], scenario builders will not succeed in predicting all possible technology breakthroughs. Nevertheless, our review of the scenario assumptions reveals that every study implies major yet different disruptive and sustaining technology changes. Thus, we conclude that innovation is key to reach any of the proposed electrified decarbonisation pathways. Despite the natural uncertainty, policy makers and scenario builders should intensify and consolidate the debate on different transport electrification paths. Not only can a shared vision of decarbonisation - including clarity on the optimal role of different innovative transport technologies - provide orientation for necessary climate and energy policy, but also can it reduce uncertainty for private investors and end-users, which can in turn replace expensive subsidies [39].

5. Our analysis coped with difficulties in the comparability of various studies. Firstly, some studies focus on a selection of electrification paths and energy end-uses, which ignores that these are competitors for the flexible use of GHG-neutral electricity. Secondly, the definitions of sectors and applications, such as heat in the industry sector and different truck segments, vary. Thirdly, different measures are used to quantify the useful energy demand in the transport sector (traction energy and ton kilometres). To enhance the significance of energy scenarios and to ease future and more detailed scenarios comparisons, we encourage scenario builders to always draw holistic electrification pictures, use more coherent modelling frameworks and promote the idea of open data. 


\section{REFERENCES}

[1] United Nations. Adoption of the Paris agreement. Framework Convention on Climate Change, FCCC/CP/2015/L.9/Rev.1. 2015. https://unfccc.int/resource/docs/2015/cop21/eng/109r01.pdf

[2] BMU. Climate Action Plan 2050 - Principles and goals of the German government's climate policy. German Federal Ministry for the Environment, Nature Conservation, Building and Nuclear Safety (BMU); 2016. http://www.bmub.bund.de/en/topics/climateenergy/climate/details-climate/artikel/climate-action-plan-2050/

[3] German Federal Goverment. Energiekonzept für eine umweltschonenende, zuverlässige und bezahlbare Energieversorgung [Energy Concept for an Environmentally Sound, Reliable and Affordable Energy Supply]. Germany, September 28, 2010. https://www.bmwi.de/Redaktion/DE/Downloads/E/energiekonzept-2010.pdf

[4] UBA. Übersicht zur Entwicklung der energiebedingten Emissionen und Brennstoffeinsaetze in Deutschland 1990-2016 [Overview of the development of the energy-related emissions and fuel usage in Germany 1990-2016]. German Federal $\begin{array}{llll}\text { Environment } & \text { Agency } & \text { (UBA); }\end{array}$ https://www.umweltbundesamt.de/sites/default/files/medien/376/publikationen/energieb edingte_emissionen_u_brennstoffeinsaetze_in_d_1990-2016.pdf

[5] Götz M, Lefebvre J, Mörs F, McDaniel Koch A, Graf F, Bajohr S, et al. Renewable Power-to-Gas: A technological and economic review. Renewable Energy, 2016;85:137190. https://doi.org/10.1016/j.renene.2015.07.066

[6] Schiebahn S, Grube T, Robinius M, Tietze V, Kumar B, and Stolten D. Power to gas: Technological overview, systems analysis and economic assessment for a case study in Germany. International Journal of Hydrogen Energy, 2015;40:4285-94. https://doi.org/10.1016/j.ijhydene.2015.01.123

[7] Marchenko OV and Solomin SV. The future energy: Hydrogen versus electricity. International Journal of Hydrogen Energy, 2015;40:3801-05. https://doi.org/10.1016/j.ijhydene.2015.01.132

[8] Sternberg A and Bardow A. Power-to-What? - Environmental assessment of energy storage systems. Energy Environ. $\quad$ Sci., 2015;8:389-400. https://doi.org/10.1039/c4ee03051f 
[9] Densing M, Panos E, and Hirschberg S. Meta-analysis of energy scenario studies: Example of electricity scenarios for Switzerland. Energy, 2016;109:998-1015. https://doi.org/10.1016/j.energy.2016.05.020

[10] Sugiyama M. Climate change mitigation and electrification. Energy Policy, 2012;44:46468. https://doi.org/10.1016/j.enpol.2012.01.028

[11] McDowall W and Eames M. Forecasts, scenarios, visions, backcasts and roadmaps to the hydrogen economy: A review of the hydrogen futures literature. Energy Policy, 2006;34:1236-50. https://doi.org/10.1016/j.enpol.2005.12.006

[12] Quiggin D and Buswell R. The implications of heat electrification on national electrical supply-demand balance under published 2050 energy scenarios. Energy, 2016;98:25370. https://doi.org/10.1016/j.energy.2015.11.060

[13] Jacobson MZ, Delucchi MA, Bauer ZAF, Goodman SC, Chapman WE, Cameron MA, et al. 100\% Clean and Renewable Wind, Water, and Sunlight All-Sector Energy Roadmaps for 139 Countries of the World. Joule, 2017;1:108-21. https://doi.org/10.1016/j.joule.2017.07.005

[14] Scamman D and Newborough M. Using surplus nuclear power for hydrogen mobility and power-to-gas in France. International Journal of Hydrogen Energy, 2016;41:10080-89. https://doi.org/10.1016/j.ijhydene.2016.04.166

[15] Vo TTQ, Xia A, Wall DM, and Murphy JD. Use of surplus wind electricity in Ireland to produce compressed renewable gaseous transport fuel through biological power to gas $\begin{array}{llll}\text { systems. } & \text { Renewable }\end{array}$ https://doi.org/10.1016/j.renene.2016.12.084

[16] Edmonds J, Wilson T, Wise M, and Weyant J. Electrification of the economy and CO2 emissions mitigation. Environmental Economics and Policy Studies, 2006;7:175-203. https://doi.org/10.1007/bf03353999

[17] Robinius M, Otto A, Heuser P, Welder L, Syranidis K, Ryberg DS, et al. Linking the power and transport sectors - Part1: The principle of sector coupling. Energies, 2017;10:956. https://doi.org/10.3390/en10070956

[18] DLR, ifeu, LBST, and DBFZ. Power-to-Gas (PtG) im Verkehr - Aktueller Stand und Entwicklungsperspektiven [Power-to-Gas (PtG) in Transport - Status quo and perspectives for development]. Study commissioned by the German Federal Ministry of $\begin{array}{llll}\text { Transport and } \quad \text { Digital Infrastructure } & \text { (BMVI); }\end{array}$ 
www.bmvi.de/SharedDocs/DE/Anlage/MKS/mks-kurzstudieptg.pdf? blob=publicationFile

[19] Oeko-Institut. eMobil 2050 - Szenarien zum möglichen Beitrag des elektrischen Verkehrs zum langfristigen Klimaschutz [Scenarios of the potential contribution of electric transport to long-term climate protection]. Study commissioned by the Federal Ministry for the Environment, Nature Conservation, Building and Nuclear Safety; 2014. www.oeko.de/oekodoc/2114/2014-670-de.pdf

[20] Prognos, EWI, and GWS. Entwicklung der Energiemärkte - Energiereferenzprognose [Development of energy markets - energy reference prognosis]. Study commissioned by the German Ministry for Economic Affairs and Energy; 2014. www.bmwi.de/BMWi/Redaktion/PDF/Publikationen/entwicklung-der-energiemaerkteenergiereferenzprognose-

endbericht,property $=$ pdf, bereich $=$ bmwi2012, sprache $=$ de, $r w b=$ true.pdf

[21] UBA. Treibhausgasneutrales Deutschland 2050 [Germany in 2050 - A greenhouse-gasneutral country]. German Federal Environment Agency (UBA); 2014. www.umweltbundesamt.de/sites/default/files/medien/378/publikationen/07_2014_clima te_change_dt.pdf

[22] DLR, ifeu, LBST, and DBFZ. Erneuerbare Energien im Verkehr - Potenziale und Entwicklungsperspektiven verschiedener erneuerbarer Energieträger und Energieverbrauch der Verkehrsträger [Renewables in transport - Potentials and perspectives of various renewable energies and transport fuel consumption]. Study commissioned by the German Federal Ministry of Transport and Digital Infrastructure (BMVI); 2015. Www.bmvi.de/SharedDocs/DE/Anlage/MKS/mks-kurzstudie-ee-imverkehr.pdf? blob=publicationFile

[23] Heilek C. Modellgestützte Optimierung des Neubaus und Einsatzes von Erzeugungsanlagen und Speichern für elektrische und thermische Energie im deutschen Energiesystem [Model-based optimisation of investment and dispatch of generators and storages for electric and thermal energy in the German energy system]. Technical University Munich; 2015. https://mediatum.ub.tum.de/doc/1230817/1230817.pdf

[24] Oeko-Institut and Fraunhofer ISI. Klimaschutzszenarien 2050 - Zweiter Endbericht [Climate Protection Scenario 2050 - Second final report]. Study commissioned by the Federal Ministry for the Environment, Nature Conservation, Building and Nuclear Safety; 2015. www.oeko.de/oekodoc/2451/2015-608-de.pdf 
[25] Robinius M. Strom- und Gasmarktdesign zur Versorgung des deutschen Straßenverkehrs mit Wasserstoff [Electricity and gas market design to supply the German transport sector with hydrogen]. RWTH Aachen Univerity; 2015. https://publications.rwthaachen.de/record/565873/files/565873.pdf

[26] Nitsch J. Die Energiewende nach COP 21 - Aktuelle Szenarien der deutschen Energieversorgung [The Energy Transition past COP 21 - Updated scenarios of the German energy supply]. Study commissioned by the German Renewable Energy Federation; 2016.

www.beeev.de/fileadmin/Publikationen/Studien/Joachim_Nitsch_Energiewende_nach_COP21_L angversion.pdf

[27] DLR, Fraunhofer IWES, and IFNE. Langfristszenarien und Strategien für den Ausbau der erneuerbaren Energien in Deutschland bei Berücksichtigung der Entwicklung in Europa und global [Long-term scenarios and strategies for the deployment of renewable energies in Germany in view of European and global developments]. Study commissioned by the German Federal Ministry for the Environment, Nature $\begin{array}{llll}\text { Conservation, } & \text { Building } & \text { and }\end{array}$ www.dlr.de/dlr/Portaldata/1/Resources/bilder/portal/portal_2012_1/leitstudie2011_bf.p $\underline{\mathrm{df}}$

[28] Palzer A. Sektorübergreifende Modellierung und Optimierung eines zukünftigen deutschen Energiesystems unter Berücksichtigung von Energieeffizienzmaßnahmen im Gebäudesektor [Cross-sectoral modelling and optimizing of a future German energy system under consideration of energy efficiency measures in the building sector]. $\begin{array}{llll}\text { Karlsruhe } & \text { Institute } & \text { of }\end{array}$ http://publica.fraunhofer.de/eprints/urn_nbn_de_0011-n-408742-11.pdf

[29] Quaschning V. Sektorkopplung durch die Energiewende - Anforderungen an den Ausbau erneuerbarer Energien zum Erreichen der Pariser Klimaschutzziele unter Berücksichtigung der Sektorkopplung [Sector coupling through the energy transition Demand for the the expansion of renewables to reach the Paris climate targets under consideration of sector coupling] HTW Berlin; 2016. www.volkerquaschning.de/publis/studien/sektorkopplung/Sektorkopplungsstudie.pdf

[30] Fraunhofer IWES/IBP. Wärmewende 2030. Schlüsseltechnologien zur Erreichung der mittel- und langfristigen Klimaschutzziele im Gebäudesektor [Heat Transition 2030. Key technologies for eaching the intermediate and long-term climate targets in the building 
sector]. Study commissioned by Agora Energiewende; 2017. www.agoraenergiewende.de/fileadmin/Projekte/2016/Sektoruebergreifende_EW/Waermewende2030_WEB.pdf

[31] Fraunhofer IWES, Fraunhofer IBP, ifeu, and Foundation for Environmental Energy Law. Interaktion EE-Strom, Wärme und Verkehr [Interaction between renewable electricity, heat and transport]. Study commissioned by the German Ministry for Economic Affairs and Energy; 2015. www.energiesystemtechnik.iwes.fraunhofer.de/content/dam/iwes$\underline{\text { neu/energiesystemtechnik/de/Dokumente/Veroeffentlichungen/2015/Interaktion_EEStr }}$ om_Waerme_Verkehr_Endbericht.pdf

[32] AGEB. Anwendungsbilanzen für die Energiesektoren in Deutschland 2013-2015 [Application Balances for the Energy Sectors in Germany 2013-2015]. German Energy Balances Group (AGEB); $2017 . \quad \underline{w w w . a g-}$ energiebilanzen.de/index.php?article_id=29\&fileName=ageb_bericht_anwendungsbilan zen_2013-2015_hjz_2016-11-29.pdf

[33] Dantzig GB. Origins of the Simplex method. Technical Report Sol. Vol. 87-5. 1987, Stanford University: Department of Operations Research.

[34] Barton J, Huang S, Infield D, Leach M, Ogunkunle D, Torriti J, et al. The evolution of electricity demand and the role for demand side participation, in buildings and transport. Energy Policy, 2013;52:85-102. https://doi.org/10.1016/j.enpol.2012.08.040

[35] Bleischwitz R and Bader N. Policies for the transition towards a hydrogen economy: the EU case. Energy Policy, 2010;38:5388-98. https://doi.org/10.1016/j.enpol.2009.03.041

[36] Sierzchula W, Bakker S, Maat K, and van Wee B. The influence of financial incentives and other socio-economic factors on electric vehicle adoption. Energy Policy, 2014;68:183-94. https://doi.org/10.1016/j.enpol.2014.01.043

[37] Klitkou A, Bolwig S, Hansen T, and Wessberg N. The role of lock-in mechanisms in transition processes: The case of energy for road transport. Environmental Innovation and Societal Transitions, 2015;16:22-37. https://doi.org/10.1016/j.eist.2015.07.005

[38] Bower JL and Christensen CM. Disruptive Technologies: Catching the Wave. Harward Business Review, 1995;73:43-53.

[39] Langbroek JHM, Franklin JP, and Susilo YO. The effect of policy incentives on electric vehicle adoption. Energy Policy, 2016;94:94-103. https://doi.org/10.1016/j.enpol.2016.03.050 